Portland State University

PDXScholar

3-1976

\title{
The evolution of the birth control movement in the United States
}

Linda B. McMahan

Portland State University

Follow this and additional works at: https://pdxscholar.library.pdx.edu/open_access_etds

Part of the Social Work Commons

Let us know how access to this document benefits you.

\section{Recommended Citation}

McMahan, Linda B., "The evolution of the birth control movement in the United States" (1976).

Dissertations and Theses. Paper 2469.

https://doi.org/10.15760/etd.2466

This Thesis is brought to you for free and open access. It has been accepted for inclusion in Dissertations and Theses by an authorized administrator of PDXScholar. Please contact us if we can make this document more accessible: pdxscholar@pdx.edu. 
AN ABSTRACT OF THE THESIS OF LInda B. MoVahan for the Master of Social Work presented March 11. 1976.

Title: The Evolution of the Birth Control Movement in the United States.

APPROVED BY MEMBERS OF THE THESIS COMMITTEE:

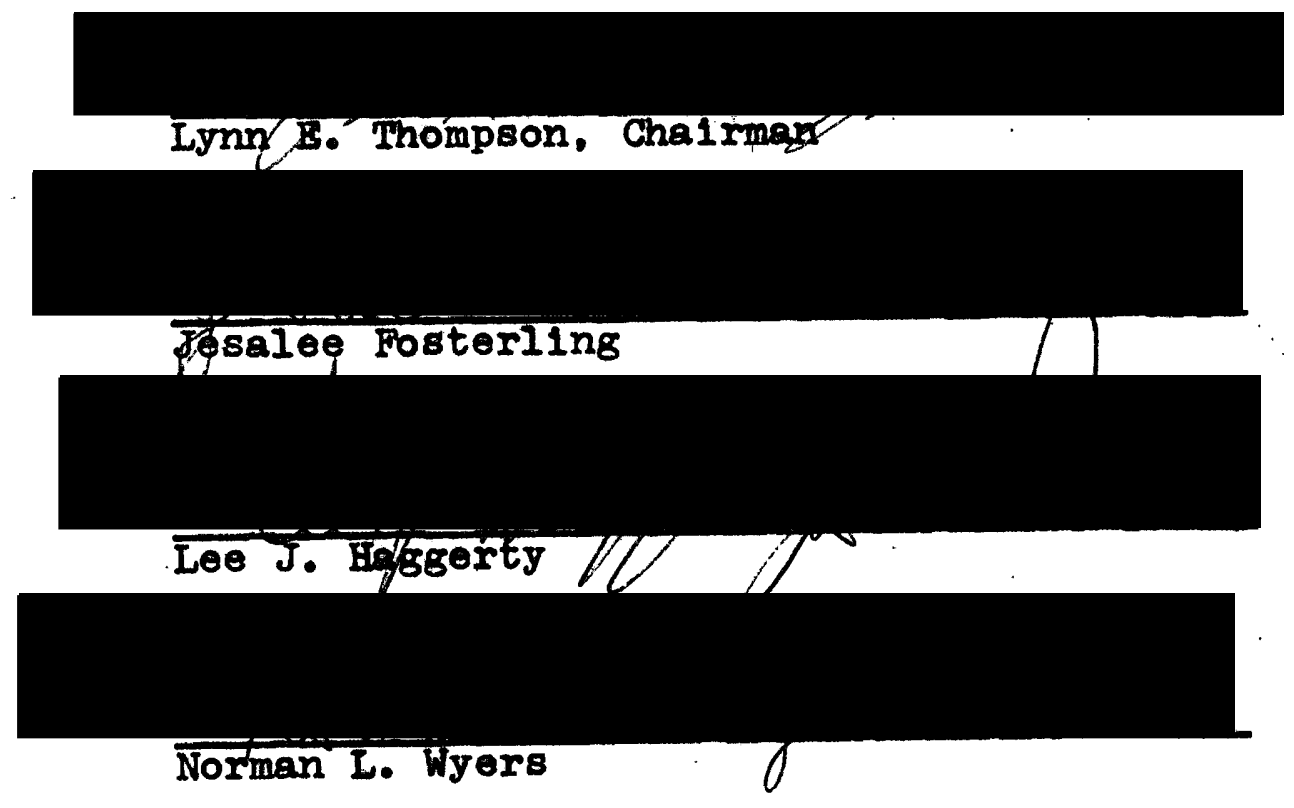

The evolution of the birth oontrol movement in the United States is the foous of this dissertation. The period of emphasis is 1873 to the present, though earlier history is briefly dealt with.

The research method used was an extensive l1brary search of the literature, followed by categorization and analysis of the data. 
The birth control movement was found to adapt to the soclological model of social movements and was discussed within this context. Two parallel movements were found to be of Importance: the birth control movement itself and the population control movement. The orlentations and relationsh1ps between these two morements are analyzed, as is the1r affect on government and public attitudes.

other components of the birth control movement are also delineated and dealt with in this dissertation. These components include social and political attitudes, oconomic issues, the role of the judiclary, the religlous influence, and the development of a funding base.

The major findings of this research are related to birth control as a social movement. First, until the 1970s it was found that the birth control movement, advocating individual rights, held the dominant emphasis. However, it appears that the population control movement is gaining influence as public awareness and ooncern increases. This 18 due in part to the gradual institutionalization of the birth control movement, that 1s, it has been absorbed into the socletal structure as a necessary and functional part of society. Second, is the transition of birth control from the shadow of illegallty it experienced at the turn of the century to the legal and respectable position of the 1970s. Third. 
the research also revealed the pattern of change regarding federal funding. This pattern indicated essentially no federal funds before the 19608, a sharp inorease and plateau during that decade, and finally, a decline in funds in the 19708. The major conclusion of this thesis is that the birth control movement has been a dynamic and important part of the twentieth century. It has had a notable impact on this society and it portends more social change and impact for the future. 


\title{
THE EVOLUTION OF THE BIRTH CONTROL MOVEMENT IN THE UNITED STATES
}

by

LINDA B. MCMAHAN

\begin{abstract}
A thesis submitted in partial fulfillment of the requirements for the degree of
\end{abstract}

MASTER OF

SOCIAL WOBK

Portland State University

1976 
TO THE OFFICE OF GRADUATE STUDIES AND RESEARCH:

The members of the Committee approve the thesis of Linda B. McMahan presented March 11, 1976.

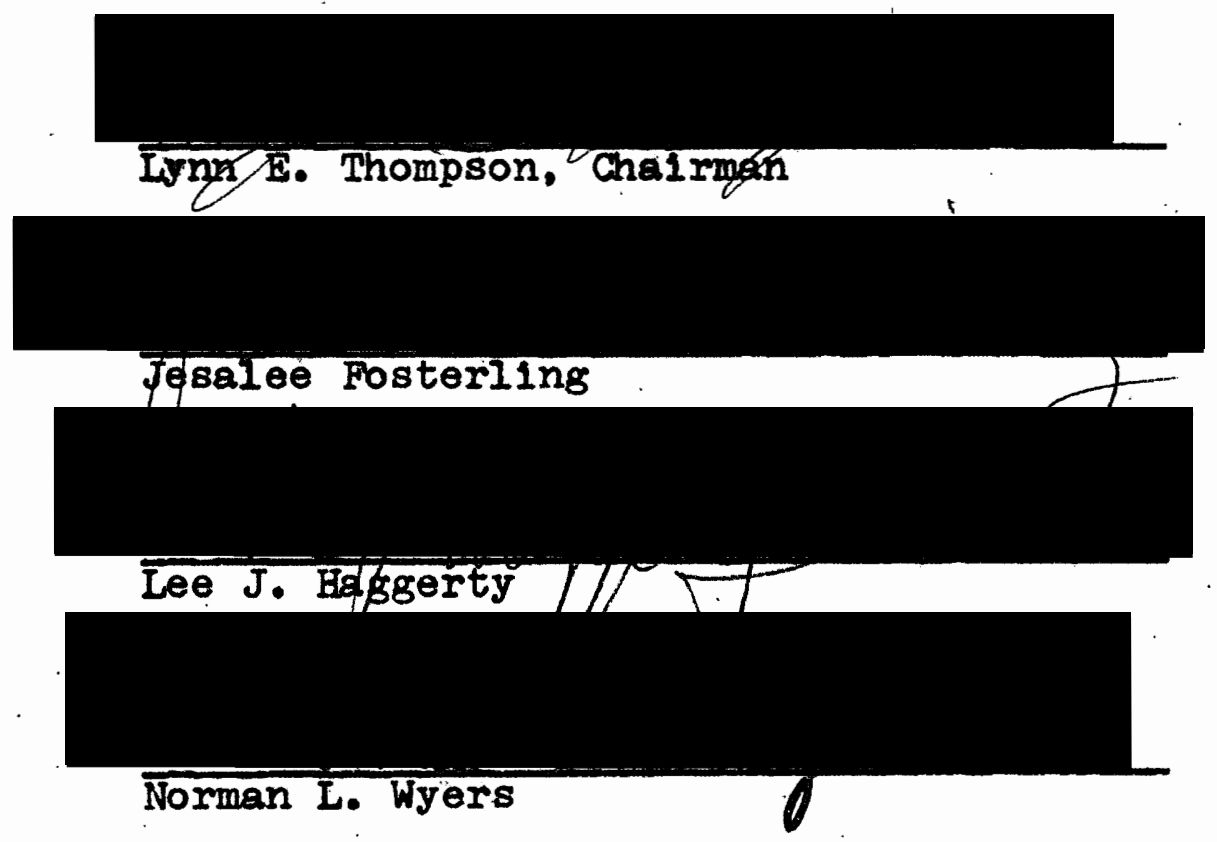

A PPROVED:

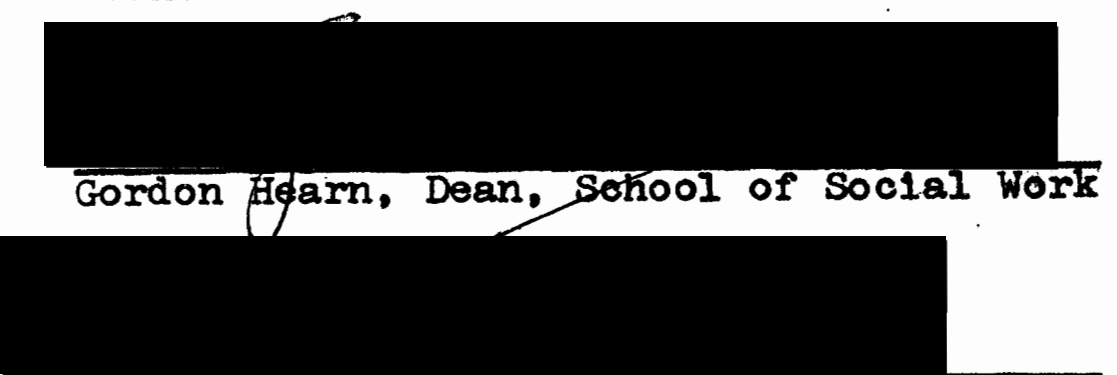

Alchard B. Halley, Dean of Graquate Studies and Besearch 
TABLE OF CONTENTS

PAGE

LIST OF FIGURES.

CHA PTER

I INTRODUCTION • • • • • • • • • •

Birth Control as a Social Movement .

Evolutionary Phases of the

Movement . . . . . . . • •

II TWO PARALLEL MOVEMENTS . • • • • • •

The orientation of the Birth Control Movement .............

The Orientation of the Population

Control Movement . . . . . .

III EARLY HISTORY OF BIRTH CONTROL • • • •

Birth Control Abroad . . . . . . 42

IV 1873-1960: THE FORMATION OF THE

MOVEMENT $\bullet \cdot \cdot \cdot \cdot \cdot \cdot \cdot \cdot \cdot \cdot \cdot \cdot \cdot$

Comstock's Iaw . . . . . . . .

Margaret Sanger . . . . . .

Social and Political Attitudes ...

Professional Attitudes Public Attitudes Social Organizations Political Attitudes

Religious Influences . ....... 
CHA P'TER

PAGE

Econom1c Issues . . . . . . .

93

V 1960-1975: GROWTH OF THE MOVEMENT •. •

95

Pol1tical Developments . . . . .

95

Social Attitudes . . . . . .

120

Heliglous Influences . . . . . .

135

Economic Issues . . . . . . .

138

Poverty Considerations

Funding Considerations

VI CONCLUSION . . . . . . • • • • •

150

REFERENCES • • • • • • • • • • • • • • • • 


\section{LIST OF FIGURES}

FIGURE

1. Growth of the Planned Parenthood

Federation of America, 1961 to

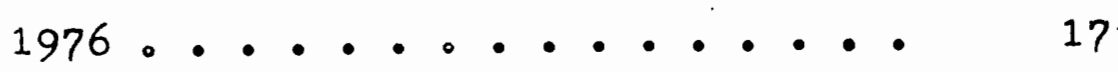

2. U.S. population growth, 1790 to 2070 - 27

3. Rate of U.S. population growth,

1800 to 1970 . . . . . . .

4. Subsidized family planning services;

U.S. need and sources -

1968 to 1975 . . . . . . . 


\section{CHAPTER I}

\section{INTRODUCTION}

This dissertation will deal with the following question: What has been the evolution of the birth control movement in the United States?

The focus will be the evolution of the birth control movement in terms of attitude, or value, changes within government and soclety, as well as polloy changes. The birth control movement w1ll also be discussed in relation to social movement theory.

Before commencing this analysis, terms will be defined. Policy, as used within the confines of this paper, refers to legislated as well as non-legislated attitudes and actions. Iegislative policy pertains to goods and services supported by public monies and benefiting. the socletal population, 1.e.. federal funding of birth control projects. (Gilbert, 1974:2) Non-legislative policy is defined as:

Elements of a society's system of social policy, a system of interrelated, yet not necessarily logically consistent, principles and courses of action. which shape the quality of I1fe or level of well-being of members of society and determine the nature of all intrasocietal relationships among individuals, social subsystems, and soclety as a whole. (G11, 1970:411) 
Birth control policy can be examined within this framework. It consists of "principles and courses of action" as well as the distribution of goods, services, and federal monies.

Pollcy has also been defined as "...a government response to a perceived problem. When that response includes funds and personnel allocated to carry out spec1fic objectives, a program is created." (Plotrow, 1973:x) Both of these definitions adequately convey the meaning that w11l be intended by the term "policy" in this paper. Birth control pollcy can be seen as the action and principles of govermment and society regarding the use of contraception to limit and space births according to individual family w1shes.

Action and prinolples relate to both legislated and non-legislated polioy. Legislative principles related to birth control are those which recognize birth control as legitimate and within the realm of governmental action. Legislative action includes bills and statutes which establish a funding base and provide for the implementation of birth control programs. Non-leglslative princlples, on the other hand, are those attitudes, values, and beliefs of. soclety in general regarding utilization of birth control. The area of non-legislative action 18 the ut111zation of birth control by members of the soolety. The term policy, when utilized in this dissertation, will be 
reflecting these factors.

Th1s analysis w1ll be restricted in that it concerns itself only with the impact of the birth control movement on national domestic pol1cy. That 1s, forelgn policy regarding birth control w1ll be dealt with only as it relates to the birth control movement in the Unlted States. and subsequent policy developments. There is considerable literature available regarding forelgn ald for family planning which, though interesting, is not particularly relevant to domestic issues.

Another area this paper w1ll not consider is the abortion controversy and policy formation around that 1ssue. Abortion is a topic worthy of comprehensive study and 1 is is not belleved that abortion and birth control can both be adequately dealt with in this dissertation.

\section{BIRTH CONTROL AS A SOCIAL MOVEMENT}

The birth control movement fits nicely into the model of a social movement; it is as a soolal movement that this author views 1t. The term social movement came into use early in the nineteenth century to describe the new industrial working class. In time, however, it came to have general connotations that applied to other movements, including birth control.

A workable definition of social movements has been sought by authors for many years. Though no two are 
exactly alike they contain the same substantive focus: collective efforts attempting to change specific social institutions and/or traditions and create a completely new social order. (\$111s, 1968:438) Perhaps a glance at some of the available definitions will help delineate just what a social movement 18, thereby providing a framework for a discussion of the birth control movement.

...group behavior directed in a concerted way at bringing about social change. (Mclaughlin, 1969:3)

...a group venture extending beyond a local community or a single event and involving a systematic effort to inaugurate changes in thought, behavior and social relationships. (King, 1956:27)

A social movement occurs when a falrly large number of people band together in order to alter or supplant some portion of the existing culture or social order.... The main characteristic of a soclal movement is that it seeks to change the culture or change the social structure or redistribute the power of control w1thin a society. (Cameron, 1966:7-9)

Soclal movements can be viewed as collectlve enterprises to establish a new order of 11 fe. They have their inception in a condition of unrest, and derive their motive power on one hand from dissatisfaction with the current form of $11 f e$, and on the other hand, from wishes and hopes for a new scheme or system of living. (McLaughlin, 1969:8)

It is important to distinguish between social movements and the effects of other small cohesive groups working to attain short term goals. Though nearly all movements have some political and social impact, they do not necessarily fit the criteria of a social movement. 
(S111s, 1968:439) The "true" social movement is seeking to achieve comprehensive change that will eventually be universally accepted. It is these movements that have historical significance.

With some idea of what a social movement 18, one might next query where does it come from and where does 1t go? Social movements find their origins in various ways, though many are generated from conflict (the orientation of the Marxist dialectic). Conflict creates energy and this leads to activity. As one author pointed out :

...movements develop out of two kinds of conditions. Either prevailing circumstances and the value structure are out of coordination with one another, or potential conflicts among values in the society are brought into the open. (Turner, 1957:501)

In looking to the origins of a movement, one sees that the birth control movement adheres to the latter condition. The passage of the Comstock Law in 1873 created a value conflict within American soclety, a conflict whlch was brought to the fore by Margaret Sanger.

Most social movements do not progress at an even or steady pace; "...1ts progress is very uneven with setbacks, reverses, and frequent retreading of the same ground." (McLaughlin, 1969:9) However, this unsteady pace often ultimately leads to what has been termed "cultural arift." 1.e., a pervasive change in the value 
system of the population. (McLaughlin, 1969:9)

Social movements, and this is partioularly true of the birth control movement, tend to start in one geographic area and move, at varying rates of speed, through the whole soclety, eventually knowing no geographic boundarles. The birth control movement orlginated in New York and for some time was relatively exclusive to that state. It eventually spread across the nation in a somewhat osmotio fashion and an active recrultment of followers began.

Another characteristic of social movements is that they usually seek to accomplish change from the bottom up, that 1s, a change from the "roots" of the society. (S1I1s, 1968:440) This would indicate that those leading the movement visualize society as changeable, pliable, and unquestionably man made.

Most movements visualize a change that is somewhat Iimited in scope. They "...accept some of the present purposes and methods of the existing order but w1sh to modify these.... Change is desired, but the existing structure as a whole is not threatened." (Cameron, 1966:23)

It $1 \mathrm{~s}$ well established that the birth control movement initially sought change in the form of improved services for the lower economic groups. It was the poor upon whom Margaret Sanger focused, the poor who had no access to birth control and adequate health care, and the poor for whom she saw change most imperative. However, 
Sanger relied on many aspects of the existing culture to help her, e.8.. the political system, the judicial system. the medical service delivery system, and the more general value orlentation to individual freedom.

Soclal movements are generally belleved to have two functions. First, they increase discussion and awareness throughout the society, ultimately leading to incorporation of the movement's 1deas into dominant publio opinion. (S111s, 1968:444) Secondiy, movements provide training for leaders so that they can continue to function and grow. The birth control movement served both functions and prompted innumerable changes in this century. Leaders are continually trained in all aspects of the movement (social, political, service delivery, etc.) and public opinion is rapidly internalizing birth control as a functional and integral part of society.

Some social movements are organized and some are not, though it is generally recognized that to be successful a movement requires at least a semipermanent organizational structure. (S11ls, 1968:448) The b1rth control movement realized this relatively early in 1 ts efforts and estabI1shed the National Birth Control League in 1915. There were other peripheral organizational structures in the movement which will be discussed later. Often a movement will have an individual leader for a time who focuses efforts and lends charisma to the cause. The birth control 
movement had Margaret Sanger, an indefatigable leader and an able recrulter of supporters.

It is the belief of this writer that one can classify the birth control effort as a fully developed social movement. It had its origins early in this century and is still functioning as a cohesive unit of people working for soclal change.

The concept of a 'social movement' is thus. suggestive of people who, on the one hand, are in the process of rejecting existing social values, while, on the other, they are both striving to make converts to their way of seeing things and dealing with the resistance that their activities inevitably call forth. (S1IIs, 1968:446)

EVOLUTIONARY PHASES OF THE MOVBMENT

This dissertation will be divided into three evolutionary phases, or time blocks, in which the birth control movement will be discussed. The first will be the earliest history of birth control unt1l 1873. Th1s was essentially a period of "no policy" on the part of the United States government. However, the early history of birth control is interesting and applicable in that it gives a sense of mankind's perpetual interest in this topic.

The second phase of development that w1ll be dealt with is the perlod 1873-1960. The year 1873 is chosen as the beginning of the discussion regarding the birth control movement in the United States because it was in that year 
that the Comstook Iaw was passed. Th1s law initiated a negative governmental orlentation; all "obscene" materials were banned from the malls and this was extended to include contraceptive information and devices. Th1s partioular law was the focal point of the struggle to liberalize societal attitudes and legislation. Th1s period saw an increasing awareness by govermment, the general publ1c, and professionals of birth control as an important issue. The organization of the national movement took place during th1s era, led by Margaret Sanger. The judiclary also played a most important role during this period by giving less restrictive interpretations of existing laws while the federal government simultaneously began to assume more social responsibilities. Th1s was the formative period of the social movement for birth control.

The last perlod to be dealt with will be 1960-1975. This perlod followed the growth of awareness and budding participation of govermment. Legislative polloy during this period continues to be fragmented and piecemeal; an explicit and comprehensive legislative polioy regarding birth control has not been achieved by the birth control movement. However, this interval has seen tremendous leglslative and executive aotivity and notable increase In services avallable to the public. The year 196018 marked as a turning point of this last era beoause of the aotivity of the Draper Committee, new technological 
advances in contraceptive methods, and John F. Kennedy's entry into the White House. These factors w11l be discussed at length later.

Phyll1s Tilson Plotrow, in the introduction to her book, World Population Crisis: The United States Response, wrote an excellent summary of policy development in general, and one which relates particularly well to birth control:

The process 1tself can be seen as three different phases - public awareness, policy development, and program implementation through which can be traced several major themes: defining and redefining the problem. giving it professional status and public notice, relating it to existing technology. guiding it through the emerging pattern of legislative innovation and executive resistance, with individual intervention at varlous stages seeking and often able to determine the resulting action. (1973:xv1)

This dissertation w1Il discuss and analyze these factors as they relate to the birth control movement. The thesis will be chronologlcally based. beginning with the early history of birth control and discussing the evolution of the movement and the extent it has affected policy formation and implementation. 


\section{CHAPTER II}

TWO PARALLEL MOVEMENTS

It is necessary to distinguish between two movements that have been parallel through both time and activity: the birth control movement and the population control (stabilization) movement. These two movements have distinct and different orientations concerning population as well as differing solutions. Some overlap of means 18 apparent, however, and 1t can be said that both movements feel their solutions are the path to the societal good.

The focus of the birth control movement is tradi-. tionally the issue of individual rights. A couple's right to decide the number and spacing of 1 ts offspring for psychological, social, economic and health reasons is deemed 1mperative. The federal government currently reflects this orlentation; the emphasis is on the individual right to voluntarily space pregnancies and limit fam1ly size. (Shlakman, 1968:82) This does not accommodate the goals of population control advocates; control of population growth, 1.e.. reduction of the birth rate, is not necessarily a consequence of chlld spacing and family limitation. However, the arguments and political 
Impact of the population control movement have helped considerably in increasing national awareness of the need for birth control. Though this dissertation focuses on the birth control movement, and consequently individual rights and voluntary utilization, it is important to discuss the population control movement and 1 ts impact on birth control in this country.

The population control issue will be introduced in this chapter in order to facilitate understanding of 1 ts impact on the birth control movement and subsequent policy developments. It is important to note that many population control advocates do not support voluntary utilization of birth control; a societal focus is belfeved more expedient in achieving the public good than an 1ndividual focus. Government's orientation at this point is toward the individual, but both perspectives have been significant in attempts at policy development and should be considered.

It has been pointed out by several authors that confusion ensues when attempting to derive a comprehensive pol1cy from two disparate and somewhat contradictory motivations. Birth control policy is especially exemplary of this. The current policy orientation is relatively singular in direction, emphasizing individual freedom of cholce and voluntary utilization. Some broadness in goal definition persists, however. As noted by Vera Shlakman in an article. "Social Pollcy Issues:" 
Family planning policy is being urged (1) to assure that every child is 'wanted';

(2) to free women from the drudgery of chronic pregnancy and the requirement of bearing chlldren against their wills;

(3) to reduce chlld dependency, that is, to cut publ1c welfare costs; (4) to reduce the social costs of child rearing; (5) to reduce poverty; (6) to prevent 1llegitimacy; (7) to foster the health and happiness of families by spacing pregnancies; (8) to encourage families not to have more chlldren than they can afford; (9) to enhance famlly well-belng by reducling the size of famliles; (10) to protect maternal health: (11) to prevent defect through reduction of births to very young or older mothers, and to others. who are at risk, and through genet1c counseling: (12) to offer to every couple the opportunity to realize the size of family to which it aspires; and (13) to control total population. (1968:83)

It is readily apparent that the birth control movement has prioritized 1ts goals, placing emphasis on individual health and family well-belng. only one reference to population control is a telling difference between the two movements; the population control movement believes stabilization of population and 1ts secondary effects are of paramount importance. Population control advocates are adamant in their conviction that voluntary birth control utilization is not sufficient to control population growth. Th1s is not to say that they believe the focus of the birth control movement is not important; however, population stabilization is believed to require broader efforts in order to achieve a reduction in the birth rate. According to Kingsley Dav1s: 
.... it does not make sense to use fam1ly planning to provide national population control or planning. The 'planning' in family planning is that of each separate couple. The only control they exercise is control over the size of their fam1ly. (1967:732)

He goes on to say "...despite strong anxiety over runaway population growth, the actual programs purporting to control it are limited to family planning and are therefore ineffect1ve." (Dav1s, 1967:738) Perhaps th1s 18 where the confusion 11es. The purported purpose of current family planning (b1rth control) leg1slation is not to control population growth, it is to insure each individual and family the right of choice. This orlentation was emphasized in the following statement by Frederick S. Jaffe, a Vice-President of Planned ParenthoodWorld Population:

The U.S. Eovernment's domest1c family planning program has been designed to help individuals achieve their own fertility goals, not to impose on individuals officially determined family size norms. The mililions of voluntary, individual fertility decisions may well add up to a national pattern that significantly affects the future growth of U.S. population, but these decisions remain individual, not societal, in origin and rationale. (1974:168)

Let us now examine the orientation of the birth control movement and population control movement in ereater detall, discussing their differences and similarities. 
THE ORIENTATION OF THE BIRTH CONTROI MOVEMENT

Research provides an important information base for outlining the significance of birth control in this country. Planned Parenthood statistics indicate that from 1966-1970, 44 percent of all bables born were unplanned (1.e.. the pregnancy was not the result of planned, deliberate effort); 15 percent of all babies born during these years were unwanted at the time they were concelved; and over half a million unwanted births occurred annually during this period. (The People Pack. 1972:125) These figures would seem to Indlcate that a large portion of our population is unsuccessful in regulating fertility. Additionally, it has been noted that unwanted births are about twice as plentiful in families earning $\$ 4,000$ a year and less than in those earning more than $\$ 10,000$. (Commission on Population Growth, 1972:165) This might be indicative of a poor service delivery system to low-income families as well as illuminating a major need for such a system. In terms of maternal and child health. birth control is an essential consideration. It is known that bearing too many children in close succession can be damaging to the mother's health. There is an increased risk of maternal mortality, anemia, high blood pressure. hemorrhage after childbirth and ruptured uterus. (The People Pack, 1972:85) Additionally, births to teenagers 
and to women over thirty have increased risks. Teenagers are particularly susceptible to hypertension, toxemia, and excessive welght gain in the pregnanoy. (The People Pack. 1972:86) The health care 1ssue has been one of the primary rationales used to promote federal awareness of the birth control $188 u e$.

Birth control services in terms of utilization also need to be examined. Are women utilizing what is avallable? In 1971 Planned Parenthood provided birth control services to 570.000 patients and the number is stead1ly 1ncreasing. (The People Pack. 1972:113) Women are beginning to utilize contraceptives at younger ages (patients under the age of twenty more than doubled from 17 percent in 1970 to 37 percent in 1971) and earlier ages (60 percent of all patients had no children in 1971 compared to 13 percent in 1966 and 49 percent in 1970). (The People Pack. 1972:113) See Flgure 1.

Health aspects of birth control have been ut1lized to advantage; legislators are increasingly reluctant to profess discrimination in the provision of health care services. Birth control fits into the health care system very well, and thus has perhaps been more readily accepted by many legislators.

The tactic of the birth control movement in emphasizing the socletal value of health care was well-grounded in social movement theory. According to one soclal move- 


\section{GROWTH OF THE \\ PLANTED PARENTHOOD FDERATIOY OF AMEPICA 1961.801976}

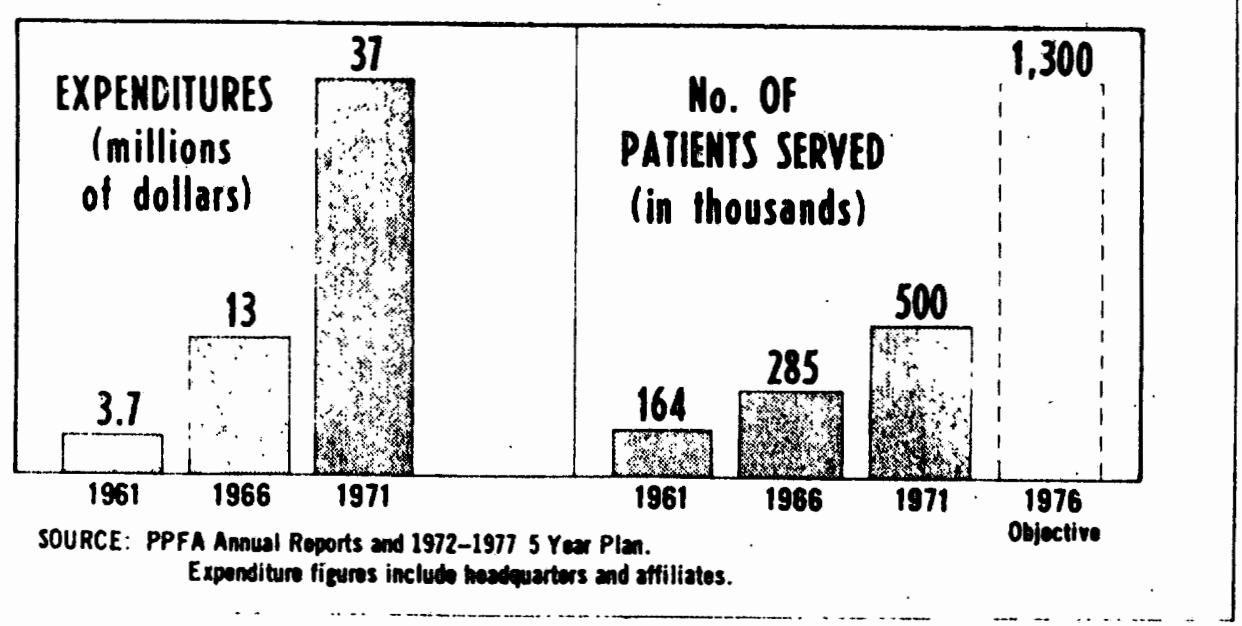

Figure 1. Growth of the Planned Parenthood Federation of America 1961 to 1976 (The People Pack, 1972:116) 
ment theorist, a movement "...endeavors to proceed by developing a public opinion favorable to 1ts aims; consequently, It seeks to establish a public issue and to make use of the discussion process." (McLaughlin, 1969:22) The health care 1ssue was well-developed by birth control advocates and very early became a central focus in their efforts.

Lack of contraceptive services to the poor have been important in determining the individual focus and goals of the federal government. It is estimated that there are 5.5 mililion low Income women in the United States in need of birth control services; only 700,000 are recelving these services. (Westoff, 1968:301) It was noted in From Now to Zero by Charles F. Westoff that. "Couples classified as poor or near-poor experienced 2.2 million unwanted blrths during 1960-1965. or 36 percent of all births to these couples." (1968:301) The Social Securlty Administration defines "poor" as families with less than $70 \not 1$ per day per family member for food; "near-poor" are those families with less than $90 \not$ per day per family member for food. (Westoff. 1968:301) The 1mpact of numerous unwanted births on these families is staggering in terms of health. nuitrition, education, environment, etc. The commission on Population Growth and the American Future was concerned with the existing inequalities for families in this group who sought birth control services: 
We can also identify and measure the limiting factors, the inequalities of opportunity, and the environmental hazards that give rise to such limitations in the quality of $11 f e, e .8$. , inadequate distribution of and access to health, education, and welfare services; cultural and social constraints in development related to race, sex, and age; barriers to full economic and cultural particlpation; unequal access to environmental quality; and unequal exposure to environmental hazard. (1972:118)

The Commission also stated that all Americans should be able to avold unwanted births regardless of age, income, or marltal status. They encouraged improvement of opportunity for 1ndividual fertility control. The Commission felt an essential basio principle for this soclety was that only wanted children be brought into the world.

Aside from the individual right to determine family size is the question of birth control's relation to poverty in an economic sense. It has been indicated that poverty and birth rates are directly related: Harold I. Sheppard wrote in Effects of Family Planning on Poverty in the United States: "...the stress is on the proposition that high birth rates among the poor are not merely a result of poverty: they are also a cause of poverty." (1967:8) Sheppard feels that lower birth rates among the poor could lead to better advantages for the chlldren who were borm, thus enabling more rapid upward social moblilty. He lists as an additional benefit the upward mobility of more heads of household if they had fewer dependents. 


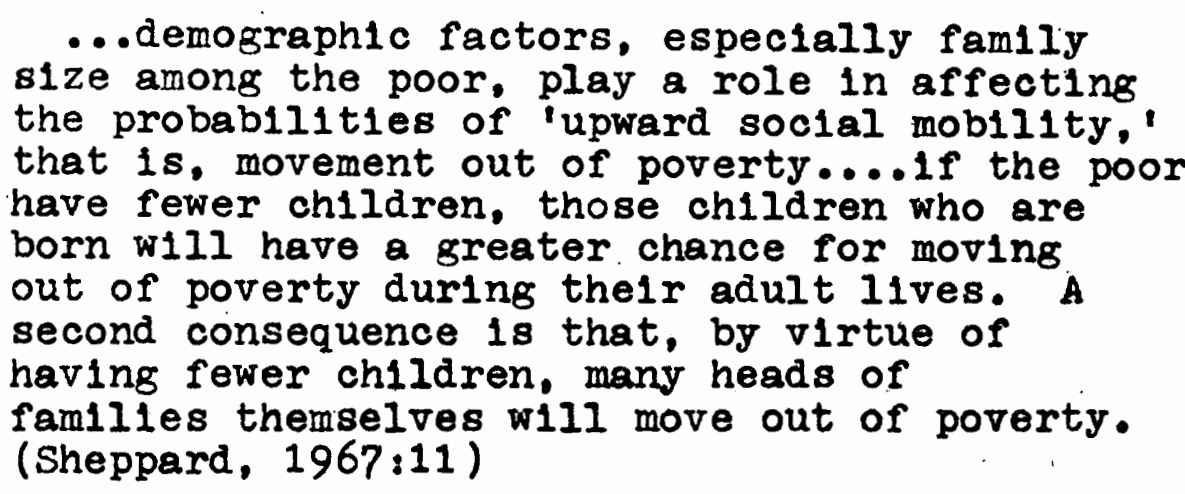

This 1dea recelved substantiation in a study that noted the amount of education a child recelves is directly related to the total number of children in the family, "...at every age and every socloeconomic level." (Sheppard, 1967:13) W1th higher birth rates and deficlent educational systems among the poor, the end result is a large number of youths entering the labor force who do not have the skills to be adequately employed. (Sheppard, $1967: v)$ Thus, according to sheppard, the cycle perpetuates 1tself:

...the crucial point is that poor families today can increase the chances for greater education for their children (and thus reduce the odds for poverty of those children by the time they become adults) in direct proportion to their efforts to practice family planning. (1967:13)

Thus, the importance of developing a national birth control policy is elucidated in an economic fashion; effective contraception 18 useful in preventing some social problems. It has been indicated that unless birth control services are made available to the poor, other programs to combat poverty will have progressively decreasing benef1ts because 
of the increasing number of persons within the poverty group. (Sheppard, 1967:1) B1rth control serv10es for the poor are seen as a cost-effective program and of great social import in terms of equalizing opportunity for social mob1lity and Individual cholce. The oost-erfectiveness aspect of birth control programs 1s: particularly attractive to economists. One projection by Planned Parenthood estimates that.

\begin{abstract}
...2 \$10 million program consisting of 500,000 women at an annual cost of $\$ 20$ per case (including adminlstrative costs) would produce savings of about $\$ 250$ million (in terms of reduoed expenditures on matermal health care, child health care. care of mental retardates, ald to dependent chlidren, and so forth). (Sheppard, 1967:19)
\end{abstract}

In summary, the birth control movement oan be seen to focus on the individual and ramily. rather than the soclety. The lack of medical services to lower income groups was pointed out by the movement and this led to examination of health in general within this group. When research indicated that birth control was indeed related to Improved maternal and child health. 1t gave the movement a perfect tie-in with established health care delivery systems and the medical profession. Matemal and child health thus became a major orientation of the birth control movement. The movement also emphasized voluntary utilization of these services, 1.e., freedom of cholce. Ut1lization studies, whioh will be discussed later. indicate that when services are readily avallable. low- 
Income groups do make use of them and birth rates drop. The birth control movement has also focused on the relationship of birth control and poverty in this country. All of these factors have influenced an orientation toward the individual and family.

THE ORIENTATION OF THE POPULATION CONTROL MOVEMENT

In a discussion of population growth it is instructive to look at historical concern with this 1ssue. It is not a new debate. The question of how many people the earth can support and how to stay within that limit has concerned philosophers for centurles. Following is a series of quotations from earlier periods related to the concern with population growth and its impact on the quality of Iife. The:writer belleves they are instructive in offering a perspective to this issue.

Han Fe1-Tzu, ca. 500 B.C., a ph1losopher in the Chou Dynasty:

In ancient times people were few but wealthy and without strife. People at present think that five sons are not too many, and each son has five sons also and before the death of the grandfather there are already 25 descendents. Therefore people are more and wealth is less: they work hard and recelve little. The Iife of a nation depends upon people having enough food, not upon the number of people. (Hardin, 1964:22)

Aristotle, ca. 322 B.C.: Most persons think that a state in order to be happy ought to be large; but even if they are right, they have no idea of what is a large and what a small state.... To the size of states there is a limit, as there is 
to other things, plants, animals, implements; for none of these retain their natural power when they either wholly lose their nature, or are spoiled. (Club of Rome, 1972:156)

Tertulilan, ca. A.D. 230, in De Anima: The strongest witness is the vast population of the earth to which we are a burden and she scarcely can provide for our needs; as our demands grow greater, our complaints against nature's inadequacy are heard by all. The scourges of pestilence, famine, wars, and earthquakes have come to be regarded as a blessing to overcrowded nations, since they serve to prune away the luxurlant growth of the human race. (Hardin, $1964: 22$ )

Thomas Robert Nalthus, 1798, in An Essay on the Principle of Population:

...the power of population is indefinitely greater than the power in the earth to produce subsistence for man. Population, when unchecked, increases in a geometrical ratio. Subsistence increases only in an arithmetical ratio.

John Stuart Mill, 1857 :

Towards what ultimate point is society tending by its industrial progress? When the progress ceases, in what condition are we to expect that it will leave mankind? (Club of Rome, 1972:129)

Harrison Brown, 1954, in The Challenge of Man's Future: ..a substantial fraction of humanity... is behaving as if it were engaged in a contest to test nature's willingness to support humanity and, if it had its way, it would not rest content until the earth is covered completely and to a considerable depth with a writhing mass of human beings.

Kenneth E. Boulding, 1956, "The Utterly Di smal Theorem":

This is the proposition that if the only check on the growth of population is starvation and misery, then any technological improvement will have the ultimate effect of increasing the sum of human 
misery, as it permits a larger population to live in precisely the same state of misery and starvation as before the change.

Freud:

The power of denial, valuable though it may be to the individual competitive man of action, is a grave danger to society as a whole.... We tend to assume that as things are now, they always have been, and there's nothing to worry about in the future. (Hardin, 1964:58-59)

\section{Santayana:}

Those who cannot learn from the past are doomed to repeat 1t. (Dachau Memorlal Nuseum)

Ronald Ridker in "The Impact of Population Growth on Resources and the Environment": An exclusive focus on resource and environmental problems, on the "running out" type of questions, misses what might be the most important consequence of population growth: change in the character of soclety. Resource and environmental problems tend to be transformed into social and institutional pressures. In the process of adjusting to such problems, society will change in ways that many of us w1ll not l1ke. (Westoff, 1973:116)

These statements are all indicative of the fact that population growth versus the supporting capacity of the earth has been of interest for centuries.

In order to take a comprehensive look at population growth and the orientation of the population control movement, it is necessary to consider the avallable demographic data. The population of the earth increased at a relatively slow rate for centuries. This rate has steadily increased as more of humanity simultaneously enter the reproductive years. Th1s is a result of increased food production, improved medical care, and 
longer I1fe spans.

At the time of Christ it is estimated that the total world population was 250 million. (Plotrow, 1973:3) The human population of this earth numbered close to four biliton by 1972. (Plotrow, 1973:3) An interesting way of viewing population growth is to look at what 18 called "doubling time." Doubling time is the period of time it takes for the total population of the earth to double. A summary of the doubling times that have been noted on earth follows:

The first known doubling of the earth's population added 250 mililion. Th1s took nearly 1700 years, from the beginning of the Christian era to the mid-17th century. At that time, the world total stood at 500 million, roughly equal to the current population of India. Since then, the tempo has quickened, especially with improvements in sanitation and health measures. The next doubling, to one billion, occurred in only 150 years, and the next took place in 120 years up to the $1920 \mathrm{~s}$. It is now expected that the 1920 total of two billion will double by 1975. In a span of only fifty-five years. (Merrill, 1969:278)

The most recent prediction noted that in 1960 population was increasing at the rate of 2 percent per year worldwlde; the conclusion reached is that the world population w1ll double again in only thirty-five years. (Merr111, 1969:278) A more current estimate by the Club of Rome states. "In 1970 the population totaled 3.6 billion and the rate of growth was 2.1 percent per year. The doubling time at this growth rate is 33 years." (1972:34) 
The bulk of this growth seems to be occurring in the underdeveloped nations of the world, who are poorly equipped to deal with 1t. It is estimated that approximately 40 percent of the population of the industrially underdeveloped world is under fifteen years of age; that 18, just entering the reproductive years. (Ehrlich, 1968:28) Additionally, one-half of the population in these nations is thought to be undernourished (too little food) or malnourished (serious imbalances in their diets). (Ehrlich, $1968: 36)$

The demographic history of the United States is equally startilng. In 1790, the year of the first census in this country, the population was recorded at four mililon. (Bogue, 1969) It 1ncreased to 100 million by the year 1917; to 200 million by 1967 (a doubling time of only 50 years); and to 208 million in 1972. (U.S. Bureau of Census, 1972) Flgures 2 and 3 Braphlcally depict the rate of U.S. population growth.

The chlef components of the rate of growth in a country are the birth rate and death rate. In the United States in 1900 the birth rate was 27 per 1000 and the death rate was 17 per 1000. (Bogue, 1969) The birth rate declined in the early 20 th century to 18 per 1000; however, the post war "Baby Boom" saw the birth rate climb as high as 26.5 per 1000 in 1947 and continue at the high rate of 25 per 1000 for the next ten years. 


\section{U.S. POPULATION GROWTH - 1790 10 2070}

\section{Child and 3 Child Pamily Averages}

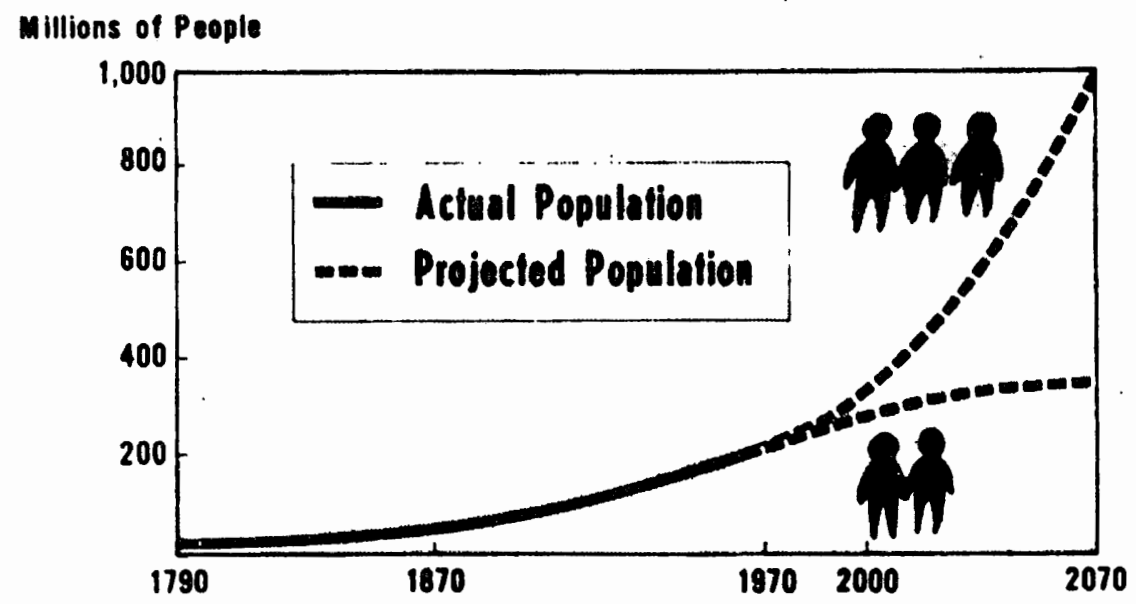

SOURCE: Commission on Peralation Crouth and the American Futuro

Figure 2. U.S. population growth 1790 to 2070 The People Pack, 1972:58) 


\section{RATE OF U.S. POPULATION GROWTH - 18001970}

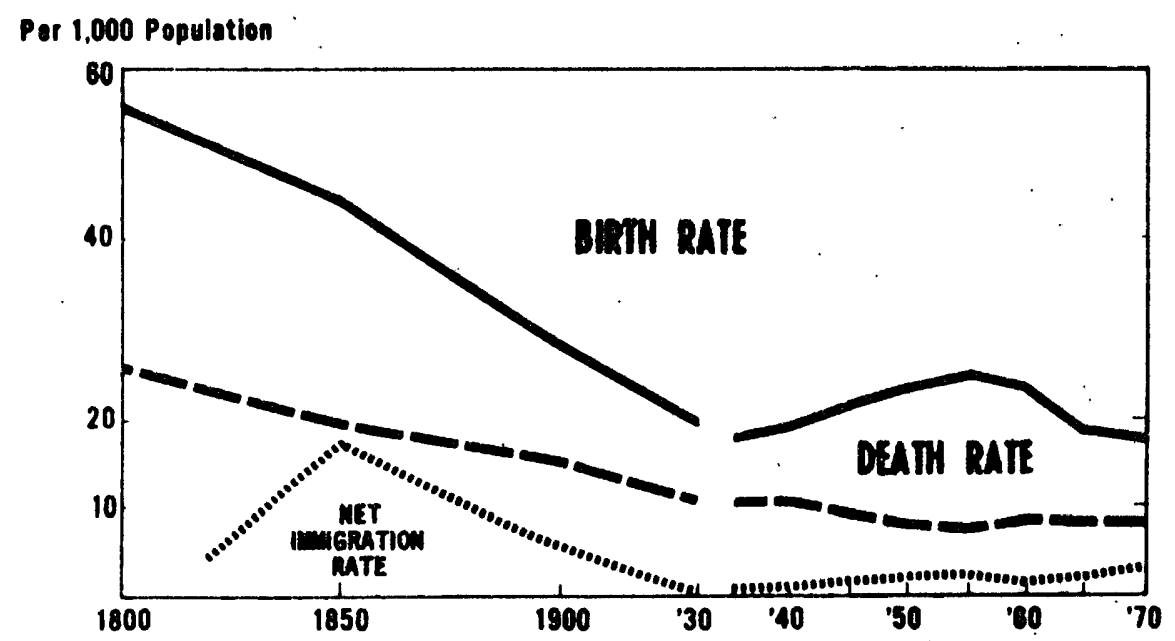

SOURCE: U.S. Consus Burew

Figure 3. Rate of U.S. population growth 1800 to 1970 The People Pack, 1972:52) 
(Bogue, 1969) Th1s growth spurt has tapered, due in part to higher value bolng placed on small families and the increasing avallability of effective contraceptives. However, even if a replacement level of population growth is reached relatively soon in this country, meaning the number of children per fam1ly would have to drop to 2.1 , it would be impossible to realize any real population stab1lity before the year 2000 (1.e.. zero growth rate). Most of the children who w1ll be reproducing prior to that date have already been born.

At the estimated $1965 \mathrm{U} . \mathrm{S}$. birth rate of 19.5 per 1000 of population, a woman who reaches the age of 45 w1II have an average of three children. To achieve a stationary population, in which parents only replace themselves, the average number of children would have to drop to about 2.1. If ch1ldbearing gradually declined to this level by 1980 ... the U.S. population would then be about $250,000,000$, and by 2020 the population would hit $300,000,000$ and remain unohanged thereafter. At that point the birth rate would have declined to 14 per 1000 and the death rate would have climbed to 14 per 1000 .

On the other hand, if present fertility and mortality trends continue, a longrange projection by the National Academy of Sciences foresees that in about 650 years there w1ll be one person per square foot throughout the United States, and in less than 1.500 years the weight of the U.S. population w1II exceed the mass of the earth, that $18,6,588,000,000,000,000,000,000$ tons! (L1llenthal, 1966)

Another 1llustration of population growth notes that if we continue to lower mortality without concurrently lowering fertility, within sixty years there wili be 
four people in the world for every one today. (Club of Rome, 1972:38) It is these facts, along w1th a myriad. of others, that have alarmed people the world over. It is these facts that have motivated the advocacy of immediate population curtailment.

One additional set of projections that should be mentioned are those concerning the number of children per family. The Commission on Population Growth and the American Future went to great lengths to predict population growth on the basis of both the two-child and the three-child family. They stated:

If families in the United States have only two children on the average and immigration continues at current levels, our population would grow to 271 million by the end of the century. If, however, families should have an average of three children, the population would reach 322 million by the year 2000. One hundred years from now, the 2child family would result in a population of about 350 million persons, whereas, the 3chlld family would produce a total of nearly a billion. (Commission on Population Growth, 1972:19)

The birth control movement maintains that U.S. population can be stabllized if recent trends to smaller families are encouraged. This can be done by expanding programs to provide voluntary fertility control services to all who do not have access to them and through expanding educational efforts to make Americans more aware of the population problem and of the individual and societal benefits of family planning. (The People Paok, 
1972:61) Advocates within the population control movement concede that this is a worthwhile goal; they disagree with the premise that education and voluntary utilization of birth control are adequate mechanisms for achieving population stability.

Turming now from the specifics of demographic data. It is appropriate to pursue a discussion of the general state of the world in regard to population growth. The opinions of specialists from various concerned professions w11l perhaps lend themselves to comprehension of this complex problem.

The Club of Rome in The Limits to Growth outlined factors to be considered in analyzing the state of the world, what is happening currently, and some predictions about the course this earth is pursuing. Five factors are noted as significant in both determining and limiting growth: population, agricultural production, natural resources, Industrial production, and pollution. (Club of Rome, 1972:11) These factors are all relevant to "...flve major trends of global concern - accelerating industrialization, rapid population growth. widespread malnutrition, depletion of nonrenewable resources, and a deteriorating environment." (Club of Rome, 1972:21) They are quick to stipulate that merely stabilizing population is not sufficlent to prevent "overshoot and collapse." (Club of Rome, 1972:142) Overshoot and collapse refers to 
the bellef that "...the basic behavior mode of the world system is exponential growth of population and capital, followed by collapse." (Club of Rome, 1972:142) The essential problem 18 that this exponential growth 18 occurring in a finite system. For centuries there was no active concerm with the size of our environment; in relative terms it was immense.

This culture has been reinforced by the apparent immensity of the earth and 1 ts resources and by the relative smallness of man and his activities. But the relationship between the earth's Iimits and man's activities is changing. (Club of Rome, 1972:150)

This changing relationship needs to be recognized and dealt with promptly.

Population control advocates belleve this calls for a change in social attitudes and government policy as well as a determined effort to control (even curtail) economic, industrial, and population growth. However, curtallment of growth has never before in history been actively pursued. There is no precedent. The deliberate control of growth has not been considered a legitimate activity in modern society. The Club of Rome emphasizes that, legitimate or not, it is imperative. As long as population increases and resource demands per capita grow, the world system will approach 1 ts limits. The ultimate outcome of this will be the depletion of the earth's nonrenewable resources. The Glub of Rome is 
unyielding on this point:

If the present growth trends in world population, industrialization, pollution, food production, and resource depletion continue unchanged, the limits to growth on this planet will be reached sometime within the next one hundred years. The most probable result will be a rather sudden and uncontrollable decline in both population and industrial capaoity. (1972:23)

This bleak forecast of man's future existence on earth has had an impact on most westerm societies and their governments. Now trends are being established, as exemplified by the declining birth rate in the United States and the increasing acceptance of the smaller family 1deal.

The Commission on Population Growth and the American Future, in noting a trend to the two-child family, also addressed itself to slowing growth in other areas of the society. The Commission particularly focused on the need to adopt a new phllosophical framework regarding growth of all kinds: bigger is not necessarily better. (Commission on Population Growth, 1972:3) They readily concur that population is a major factor affecting the demand for resources and the deterioration of the environment. "From an environmental and resource point of view, there are no advantages from further growth of population beyond the level to which our past rapld growth has already committed us." (Commission on Population Growth, 1972:56) Slowing our population growth would not only have 
environmental benefits, but would lessen the burden placed on governmental services as well as increase per capita income for the population. The commission noted three definite advantages to slower growth in this country: the average person would be better off in terms of traditional economic values, nonrenewable resources would be conserved, and pressure on the eduoational and other systems would be reduced. (1972:117)

The attitudes of the demographers have been discussed in defining rapid population growth. Environmentalists are another highly vocal group concemed with population growth. Many environmentalists decry population growth as the chief, and many times only, cause of the deterioration of our world and the quality of 11 fe we find in 1t. This 18 a much more specific focus than that of the multi-disciplinary Club of Rome. The Club of Rome is an active group who's contentions have increased awareness and thus contributed to the birth control movement. They have brought the problem to the public's attention. Paul Enrlich, author of the Population Bomb. states:

The causal chain of the deterioration is easily followed to its source. Too many cars, too many ractorles, too much detergent, too much pesticide, multiplying contra1ls, inadequate sewage treatment plants, too little water, too much carbon dioxide - all can be traced easily to too many people. (1968:66-67)

Environmentalists have noted that the United States has 
only 6 percent of the world's population, but consumes 30 percent of world resources. (Ehrlich, 1968:133) An analogy that gives substance to these figures is that one American birth indicates use of 25 times more world resources than one Indian birth. (Callahan, 1971b)

Another outcome of continued population growth stressed in the environmental viewpoint is that food production will not keep up, leading to higher food prices. By the year 2000 it 18 est1mated that "...all high quallty land will be in use and 50 million acres of lower quality land will also have been farmed, requiring a larger investment in fertilizers, labor, irrigation, etc." (The People Pack, 1972:79) Inevitably, this will lead to higher and hlgher food prices. Food is considered a replaceable resource, though it is doubtful that it can be replenished fast enough to meet growing demands. Other renewable resources, such as wood, w1ll enoounter comparable problems.

Frank Notestein. President Emeritus of the Population Counc1l, has perhaps summed up the view of many specialists concerned with population growth:

Zero growth 1s, then, not simply a desirable goal. it is the only possibility in a finite world. One cannot object to people who favor the inevitable. (Notestein, 1970:20)

The population control movement can be summarized as a movement advocating immediate ourtaliment of population growth with eventual stabilization of the population. In this sense it is a broader movement than birth control; it 
incorporates birth control's major mechan1sm, contraception, but extends itself to other additional means. The additional mechanlsms utilized or recommended by the population control movement were well stated by Bernard Berelson, president of the Population Counc1l. He noted that our nation was subtly pronatalist and that this had to be dealt with as well as establishing birth control service delivery systems. He felt there were several mechanlsms by which the govermment could approach th1s pronatalist issue, many of them retaining a large degree of freedom of choice for the individual:

1. Extensions of voluntary fertility control could be utilized, such as liberalized abortion laws and the institutionalization of maternal care.

2. Involuntary fertility control could be established, such as mass use of fertility control agents, l1censed parenthood, temporary sterilization, compulsory sterilization after three children, etc.

3. Educational campalgns could be increased, both in funding and soope.

4. Incentive programs could be developed, such as payment for effective birth control or sterilization or a bonus for child-spacing.

5. Shifts in social and economic institutions were called for, particularly acceptance of childless marriage as legitimate and respect for the working female;

a change 
in marriage laws 18 encouraged to increase the average age at first marriage.

6. The need for increased research to develop new and better methods of birth control is particularly emphas1zed. (Berelson, 1969)

The Commission on Population Growth and the American Future dealt with many of these issues and considered them legitimate. A change in basic social attitude and orlentation was considered essential for ultimate stabilization of population.

Governmental actions that can effect childbearing decisions by individual couples include the laws regulating marital status....; laws directly regulating fertility control (contraception and abortion); tax polloy on income, property and inheritance; housing regulations and subsidies, urban renewal programs, and welfare policies; food subsidies; health programs; ald to families w1th dependent ohildren; f1scal support of formal sohooling; allocation of expenditures to 'male' or 'female' sectors of the economy; even the draft law. (Commission on Population Growth, 1972:150)

The population oontrol movement has consistently focused on stablization of population growth, maintenanoe of the human society, and continued existence in a world of finite resources. All of these focuses connote a macro, or societal, perspective. The birth control movenent, on the other hand, has maintained a persistent focus on health 1ssues, poverty, and freedom of choice; this connotes a micro, or individual, perspective. These are two obviously different orlentations. 
As the birth control movement has accelerated there has been increasing competition between these two ideologies for publiolty. legislative emphasis, and public support. This public debate has done much to draw public attention to the subject of birth control. 


\section{CHAPTER III}

EARLY HISTORY OF BIRTH CONTROL

Every civilization this earth has known has sought ways of controlling fertility. The goal is not new. Several of the methods utilized today, in "modern" socleties, have their roots far in the past. It would seem that unlimited reproduction has long been recognized as a bane to the health of both individuals and society.

Men and women have always longed for both fertility and sterility, each at its appointed time and in its chosen circumstances. This has been a unlversal a1m, whether people have always been consclous of it or not. (Himes, 1936:179)

Early civilizations all participated in the search for a good method of fertility control. The Chinese, in the first written medical reports, gave instructions for abortions over 4000 years ago. (Douglas, 1970:63) The Petri Papyrus, written in 1850 B.C. during the reign of Amenemhet III, contains the oldest written medical prescriptions for contraceptive methods. (Westoff. 1968:42) Among other methods, the papyrus discusses using suppositories made from honey and alligator dung. (Douglas, 1970:63) A second Egyptian record, the Elbers Papyrus, dating from 1550 B.C., also describes methods 
of contraception. (Westoff, 1968:43)

The Hebrews, Hindus and Persians all left prescriptions for various suppositories believed to be useful in preventing conception. (Douglas, 1970:64) It 1s also known that the Jews, Greeks and Romans had knowledge of contraception. Plato and Aristotle both made public pronouncements supporting contraceptive use. Plato wanted to restrict the right to bear children by age; he urged passage of a law that would allow women to be pregnant only between the ages of twenty and forty, and for men to father children only between the ages of thirty and thirtyf1ve. (St. John-Stevas, 1971:5)

The sixteenth century saw the advent of an institution in terms of birth control. In 1564 Gabriele Fallopio published De Morbe Gallico, a treatise on venereal disease In which he discussed the condom or sheath. (st. JohnStevas, $1971: 14$ ) This was the first published account of the condom, though historlans believe it had been in use for some time previously. At this time it was used primarily for the prevention of venereal disease. It was not until the elghteenth century that the condom was used as a method of contraception. (Westoff, 1968:44) The condom 18 still the only method of birth control that is also effective in preventing the spread of venereal disease. The early history of birth control in the United States is relatively vold of written accounts. However, 
observations were periodically made by astute citizens. Benjamin Franklin observed that the population of the colonies had doubled in only twenty-five years, encouraged by the apparent immensity of the land. Th1s prompted early marriages with famliles averaging elght chlldren. Franklin subsequently noted that the chief restraint in the growth of any species, be it plant or animal, was overcrowding. In looking back to the 01d World, he postulated that "mutual interference" between population and a Iimited food supply helped to keep the population stable. He stated, "Wlthout such interference, any species would proliferate until it finally covered the earth." (Douglas, 1970:64) These observations by Franklin served as the catalyst for Thomas Malthus and his theory, which was publ1shed in 1792.

An aditional factor in early attitudes toward, and use of, contraceptive measures was the position of govermments. For centuries it has been the pollcy of countries losing a war, or losing geographic holdings, to encourage population growth. "Contraception and declining birth rates seemed to be assoclated with declining power." (P1otrow, 1973:10) This attitude st1ll exists, Including within the United States, and there are those who continue to advocate a growing population as an indication of political and economic power. 
BIRTH CONTROL ABROAD

The development of the birth control movement in England and of Holland's service delivery system is also relevant. Both of these countries had an impact on the development of the American birth control movement.

Francis place launched the birth control movement In England in 1822 when he wrote and distributed two handbills: "To the Married of Both Sexes" and "To the Married of Both Sexes in Genteel L1fe." (Hardin, 1964: 195) These handbills were the flrst explicit material to be published regarding avallable contraceptive methods. Francis Place firmly belleved that population needed to be limited in terms of both societal and individual needs. He found a supporter in John Stuart Mill, who in 1822 wrote:

By checking population no pain is inflicted, no alarm excited, no security infringed. It cannot therefore, on any principles, be termed immoral..... if it tends to elevate the working people from poverty and ignoranoe to affluence and instruction $I$ am compelled to regard it as highly moral and virtuous. (st. JohnStevas, 1971:16)

A period of establishing support for the birth control movement followed in England. Simultaneously, in America, a book was published that was to help launch the British movement, though 1t had little impact on the country of 1ts origin. Dr. Charles Knowlton, a Massachusetts physiclan, published in 1832 a small treatise which 
he titled Fruits of Ph1losophy. (St. John-Stevas, 1960:7) This was a short account of contraceptive methods which could be utilized to limit family size. Dr. Knowlton was sentenced to a term in prison for writing obscene material and the book was banned in Amerlca. However, it caught the eye of several birth control advocates in England; a copy was obtained and published there in 1877. (Hardin. 1964:202) These supporters were Annie Besant (1847-1933) and Charles Bradlaugh (1833-1891). Besant and Bradlaugh were also arrested on charges of publishing obscene material. It was at this point that the supporters of the birth control effort in England united; Dr. Alice V1ckery and Dr. Charles Drysdale organized the NeoMalthusian League in 1877 as a direct result of the BesantBradlaugh arrest and trial. (Sanger, 1931:99) Besant and Bradlaugh organized their own defense and developed a strategy based on obtaining a more liberal interpretation of the existing law. This was significant, for later Margaret Sanger was sufficiently impressed with their approach that she adopted an identical strategy for the movement in America. Besant and Bradlaugh were initially convicted, but the court of Appeals reversed the decision. In 1878 the Neo-Malthusian League elected Annie Besant as 1ts first secretary. The League then proceeded to advocate early marriage with instruction in contraception. (Sanger, 1931:199) Earlier, Thomas Malthus had encouraged 
late marriage with abstinence until then; he opposed the use of artificial methods of birth control. (Sanger, 1931: 100) This is an interesting note, in that the NeoMalthusian Ieague dubbed themselves heirs of Malthusian doctrine.

Following the Besant-Bradlaugh trial of 1877, few attempts were made in England to suppress birth control by law. It took many years for birth control to gain general public acceptance in England, but the BesantBradlaugh trial established the legal foundation to make this feasible. The removal of legal suppression paved the way for more publications. Some of the publications from England (both before and after the 1877 trial) included:
1831
1866
Moral Physlology, R.D. Owen
1877 Sexual Phys10Iogy, Dr. H.T. Thrall Fruits of Fhilosophy, Dr. Charles KnowIton (published by Besant and Bradlaugh in England)
1877 The Wife's Handbook, Dr. H.A. Albutt
1879 The Law of Population, Annie Besant
1911 The Malthusian Handbook
1913 Hyolen1c Methods of Fam1ly Limi- tation, Malthusian Learue (Sanger, 1931:100)

The birth control movement in Holland also had an impact on American att1tudes, especially in establishing goals of the movement and in the example it set for the world. It 18 definitely worthy of mention.

Since the late nineteenth century Holland had set an example by delineating the positive effects of contraception on individual health and society at large. 
They documented a measurable increase in overall health in the Dutch population as well as a decrease in venereal disease and prostitution. Very early in 1ts existence, the Dutch birth control movement indicated that they were not trying to control population growth. The goal was to increase the health of the population and insure a good ilfe for all through family limitation and child spacing. (Douglas, 1970:81) These are essentially the same goals espoused by the American birth control movement, though they have not been as clear regarding population control. The competition between the American birth control and population control movements has led birth control advocates into the arena of population stabilization. In order to maintain public and legislative support the American birth control movement has put increasing emphasis on 1 ts effort to stabllize population growth; a much different approach than the Dutch counterpart.

In $1878 \mathrm{Dr}$. Aletta Jacobs founded the first birth control clinic in Holland and in the world. (Sanger, 1931: 113) Following th1s, Dr. J. Rutgers opened and supervised additional clinics to serve the bulk of the population.

A brief look at the sequence of events in Holland follows :

1876 Dr. S. VanHouten, Minister of the Interior, wrote an article favoring the Neo-Malthusians

1879 International Medical Congress was held in Amsterdam with Dr. Charles Drysdale the key speaker 
1882 Dr. Aletta Jacobs opened a clinic for the poor in Amsterdam giving contraceptive information

1886 Thirty-five doctors jointly published a pamphlet describing contraceptive methods

1892 Practical information was avallable to the poor in at least four Dutch clinics

1895 Government gave the League a Royal Decree for public service

1899 Dr. and Mrs. Johannes Rutgers took over leadership of Dutch NeoMalthusians and spread it throughout the country (Sanger, 1931:114)

The British and Dutch were well ahead of the United States in accepting the efficacy of birth control for their populations. While the Dutch Neo-Malthusians were recelving Royal Decrees, Americans were belng arrested for the same activities! It took the United States considerably longer to reach a comparable level of soclal and political recognition of the legitimacy of birth control. The entire period during which the Dutch and British were active was essentially a perlod of no-policy in the United States. Birth control was still considered a generally unspeakable subject. 


\section{CHAPTER IV}

1873-1960: THE FORMATION OF THE MOVBMENT

\section{COMSTOCK'S LAW}

The turning point in the United State's no-polloy attitude regarding birth control occurred largely through the efforts of one man. Anthony Comstock. Following the CIV1l War, Congress banned all obscenlty from the U.S. ma11, but pornography continued to be available. Comstock was determined to close all legal loopholes allowing the pornographic business to continue. He lobbied industriously in Congress and on March 3, 1873. President Grant signed what was known as the comstock Bill into law. It excluded the previous exemption of physicians regarding contraceptive Information and banned all "...obscene, lewd, lasolv10us. f1lthy, and indecent" materials from the ma118, inoluding information and devices for the "prevention of conception." (Douglas, 1970:46) This law was directed at the postal service, but was inclusive enough to have a truly stifling effect on the spread of contraceptive knowledge in this country. It is interesting to note that on Narch 4, 1873. the day after the bill was signed into law, Anthony Comstock was named special agent for the Postmaster General. (Douglas. 1970:46) 
Following the passage of the bill and his new appointment, Comstock organized groups throughout the country to help in his fight to suppress vice. Exemplary was the New England Watch and Ward Soclety. (Douglas, $1970: 47)$

Comstock was a fanatic in every sense of the word. He was overly zealous in pursuing his calling, to such a degree that it has taken this country a considerable time to recover from his activities. It was once sald of Comstock: "...1t had become obvious that Anthony Comstock could not distingulsh between pornographic, medical, soclological and aesthetic works." (Douglas, 1970:47)

It was against the wall of sllence created in large part by this one individual that Margaret sanger was to wage her war. It was Anthony Comstock who initlated a legislative birth control policy that was repressive. negative, and close-minded. Not until well into the twentieth century ald the attitudes and barriers erected with the passage of the Comstock Law crack.

Comstock may, in a paradoxical way, also be seen as an initiator of the American birth control movement. Social movements are often generated by conflict or by two groups viewing each other as enemles. The Comstock Law brought to the fore the value conflict regarding the provision and utilization of contraoeptive methods within this country. Anthony Comstock's lan became the focal point and chief 
antagonist of the American birth control movement. Margaret Sanger was the founder of the movement that brought the law's inevitable tumble, and it is well that we consider her $11 f e$ and activities before going further.

\section{MARGARET SANGER}

Margaret Sanger was born in Corning, New York, in 1879, six years after the passage of the Comstock Law. (Douglas, 1970:2) Sanger's famlly was large and poor. Later she was to say of her childhood: "Very early in my chlldhood I assoclated poverty, toll, unemployment, drunkenness, cruelty, quarreling, fighting, debts, and jails with large families." (Sanger, 1931:5) She extr1cated herself from the poverty to which she had been born and studied nursing. It was her work as a nurse that eventually led her into the struggle to liberalize attitudes and law regarding birth control.

In the summer of 1912 , Sanger was working with obstetrical cases in the New York slums. Sadie Sachs was a young patient with whom she first had contact following a self-induced abortion. Sadie was near death, but sanger helped nurse her back to health over a long period of convalescence. On her last visit with Sadie the doctor on the case was present. Sadie was recuperating, but was frantic with worry over the possibility of another pregnancy. She pleaded with the doctor to tell her how 
to prevent another conception as Sanger 11stened. The doctor was unable to advise her, but before leaving he sald, "Tell Jake to sleep on the roof." (Douglas, 1970: 32) After the doctor's departure, it is said that sadie turned to Sanger with the same question, but she didn't know the answer either. She left Sadie that day and walked the streets for many hours, puzzling over the plight of so many women bearing so many unwanted chlldren, or dying from abortions badly performed. Sanger did not return to see Sadie until she recelved a distraught phone call some months later. It was Jake Sachs; Sadie had attempted another abortion after discovering she was pregnant again. Sadie was dead within minutes after Margaret Sanger's arrival. This is a somewhat lengthy anecdote, but necessary. According to Douglas, 1t was this death, this one woman's suffering. that ignited in Margaret Sanger a desire to do something to prevent any more such tragedies. Sadie Sach's death lit a spark in Margaret Sanger that never went out.

This incident, and the changes it wrought in Hargaret Sanger, christened her as one of the early advocates of women's rights in this country. Her desire to improve the social situation of women and give them control over their own lives and bodies la1d a foundation of concern that was to grow into a social movement in its own right, the women's rights movement. The birth control 
and women's rights movements have utilized each others contentions, enhancing their own interests as well as serving the other. This phenomenon 18 not uncommon between soc1al movements. (Cameron, 1966:169)

Sanger proceeded with her efforts by reading every medical journal and related writing she could find that might give her some clue as to effective means of contraception. She could find nothing. The Comstock Law had created a literal vacuum within the medical profession. (Douglas, 1970:35)

S2. Danizl Kentudity

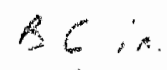

Amsicican where she was determined to investigate French methods of Po. 19 birth control. In France she found that fertility control was an accepted way of $11 \mathrm{fe}$, due largely to a government policy established during Napolean's rule. The government decreed that a man's chlldren would share equally in his estate. Instead of the old laws of primogeniture. This gave the males of the society an economic incentive to limit fam1ly size. (Douglas, 1970:39) Th1s pol1cy was a means of controlling population as well as limiting individual births.

It was in France that Sanger discovered the pessary, or diaphragm; this was a contraceptive device not mentioned in the American literaure, though highly effective. It is a rubber dome fitted to a spring that effectively. covers the cervix, thus preventing sperm from entering the 
uterus. Sanger was ecstatic. She had found an effect1ve method for which women could take responsibility. She returned to America with an abundance of information, great enthusiasm, and a supply of diaphragms.

In March 1914 the first issue of the Woman Rebel appeared. (Douglas, 1970:50) This was a magazine through which Sanger hoped to reach large numbers of American women. She received over 10,000 requests for contraceptive information after the first 1ssue. (Sanger, 1931:80) Though she did not mention contraception directly in the first 1ssues, she was indicted for nine alleged violations of the federal statutes (Comstock Law). (Douglas, 1970:50) Judge John Hazel postponed her trial in order to allow her time to prepare a defense; while doing this she simultaneously began compliling all she had learned in France in a pamphlet titled Family Limitation. (Douglas, 1970:50) The judge set Sanger's trial date for october 1914; her defense was not yet ready. Sanger literally fled to Europe. though courteously leaving letters for the judge and district attorney explaining she would return when her defense was adequately prepared. As soon as she was afloat on the Atlantic, Sanger wired her friends to release Family Limitation. (Douglas, 1970:550) When Comstock saw this most recent publication, he decrled her as ".... heinous criminal who sought to turn every home into a brothel." (Douglas, 1970:85) W1ll1am Sanger, Margaret's 
husband, was arrested shortly after the pamphlet's publication after unknowingly giving his only copy to a postal agent. Judge McInerney, presiding at his trial, comdemned the pamphlet as indecent, 1mmoral and a menace to soclety. (Douglas, 1970:85) However, the public had been awakened and began to respond to the Sanger charisma. Letters poured in to the district attorney and Judge Clayton urging dismissal of charges against Margaret and her husband. Her trial was finally rescheduled for February 18 , 1916. (Sanger. 1931:139) Following several pronouncements, the government entered a "nolle prosequi," a decree ending prosecution. (Sanger, 1931:139) The memo dismissing the case claimed the government was dropping charges only because of public sentiment that held the defendant was being persecuted. The memo was signed by United States District Attorney, H. Snowden Harshall. (Sanger, 1931:139) Margaret Sanger was home, and free, for the time belng. In 1914, amidst her other activities, Sanger founded the National Birth Control League and named the movement "birth control." (Sanger, 1931:83) Some debate ensued before settling on the term birth control. Other titles considered included Malthusianism, conscious generation, voluntary parenthood, voluntary motherhood, preventception, the new motherhood, constructive generation. family control, race control, and birth-rate control. (sanger, 1931:83) Some of these terms indicate an early, 
if not primary, interest in population control by the leaders of the birth control movement. Sanger hoped that the newly formed League would be able to pull together support from all areas of the United States. The movement was extending its geographic bounds, as all social movements eventually do.

Sanger's planned strategy was to use the precedent established by the Besant-Bradlaugh trial in England in 1876; she wanted the higher courts to glve more I1beral rulings on existing statutes. This would allow her to use the trial forum as an arena of debate to awaken public interest and support.

October 1916, the dismissal of charges behind her, Sanger opened the first birth control clinic in this country. (Douglas, 1970:102). The site was Brownsville, New York. It was the only clinic of its kind outside Holland. The dlaphragm, whlch Sanger had brought from France, was the means of contraception presortbed for women using the clinic's services.

The handbills advertising the opening of the clinic were printed in three languages: English, Y1ddish, and Italian. They read as follows:

Mothers.

Can you afford to have a large family?

Do you want any more chlldren?

If not, why do you have them?

Do not kill. Do not take $11 \mathrm{fe}$, but

prevent. Safe, harmless information

can be obtained of trained nurses. 
46 Amboy Street

Near P1tkin Avenue

Brooklyn

Tell your neighbors and friends. All mothers welcome. A registration fee of $10 \phi$ entities any mother to this

information. (Douglas, 1970:104)

In November 1916 the Brownsville Clin1c was raided; all working there were arrested for violation of Section 1142 of the New York Penal Code. (Sanger, 1931:161). Th1s section prohibited dispensing of contraceptive information for any reason. Ball was arranged and Sanger re-opened the clinic. Again she was arrested, this time on the charge of "maintaining a public nuisance." (Sanger, 1931: 161) She engaged an attorney, J.J. Goldstein, who was to work with her on this case and throughout the next four years. (Douglas, 1970:109) The trial was held in February 1917. Sanger refused to plead gullty; she was convicted. Her sentence was thirty days, which she served in the Queens County Penitentlary. (Sanger, 1931 : 176) She was released on March 6, 1917. (Sanger, 1931:184) In February 1917 the first 18sue of the Birth Control Rev1ew was publ1shed. (Sanger, 1931:191) Sanger and others had been working diligently on this project throughout the Brownsville Clinic ralds, hearings and trial. It was hoped that the Review would serve as a communlcation system for birth control advocates across the country, a necessity for any social movement. Fred Blossom was the original manager and editor. (Douglas. 1970:127) The 
Review took a great deal of Sanger's time from the years 1917-1921. She hoped to gain the support of the wealthy and intelligent women of the country; their cooperation in protesting repressive laws and influencing public opinion would be invaluable. (Sanger, 1931:191) The Review was one of the tools for achleving this end. Sanger had very early become aware of one of the principles of social movements: the necessity of enlisting the middle-class public if policy and attitudes are to be effectively changed.

The reform movement, while usually existing on behalf of some distressed or exploited group, does little to establish its strength amons them. Instead, it tries to enlist the allegiance of a middie-class public on the outside and to awaken within them a vicarious sympathy for the oppressed group." (MoLaughlin. 1969:22)

J.J. Goldstein meanwhile appealed the decision regarding the closure of the Brownsville Clinic. In 1918 Judge Frederick E. Crane of the Appellate Division- State Supreme Court gave a decision in the case. He stated that since sanger was not a physiclan she was not covered by the state law's exemption. However, an important interpretive victory was gained when the judge stated that a physician could legally give contraceptive advice for "...the cure and prevention of disease." (Douglas, 1970:135) The victory was associated with the definition of "disease." The judge relled on Webster's definition: "... any change in the state of the body which caused or threatened pain and s1okness." (Douglas, 1970:135) Th1s 
interpretation allowed the law to be stretched well beyond its original meaning. Sanger was pleased with the outcome of the appeal.

Taking everything into consideration, my campaign was a great success. I had created a national public opinion in favor of birth control, had won the press to discuss the subject, had inspired the organization of leagues to carry on the work throughout the country, and had aroused the nation to a real1zation of 1ts great moral duty toward womanhood. (Sanger, 1931:149)

She began to move more steadily toward her goal of a national campalgn. Her strategy included four steps: agltation, education, organization, and legislat1on. (Sanger, 1931:190) The agitation, or increasing of awareness, had been accomplished. She was ready to move forward.

In 1921 Sanger spearheaded the First National Birth Control conference. It was purposefully timed to colnclde with the American Public Health Conferenoe in order to reach physiclans who might attend. Th1s conference did much to awaken physicians to their responsibilities in the area of birth control. Sanger invited Barold Cox, a former member of the British Parliament and editor of the Edinburgh Review, to speak at a rally following the conference. (Douglas, 1970:160) The toplc of the rally was to be "Birth Control: Is It Moral?" Leaders of all religlous demonimations were invited to attend, including Catholic. Arriving at the hall, the entourage found the 
doors locked by orders of Monsignor Dineen and Archbishop Patrick J. Hayes. (Douglas, 1970:160) The Cathol10 Church had made its position quite clear. The group found another meeting hall that night. Margaret Sanger had strong feelings when asked who her most zealous opponents were :

The Roman Catholic hierarchy of course; but along with them all the forces of reaction, the hopeless dogmatists of the ages; the conformists: the reactionaries - call them Lutherans or Purltans or Fundamentalists or Pharlsees - all those for whom morallty means merely blind subservience to custom and tradition, to a code completed and rigid for eternity. They explain every occurrence that inflicts unhappiness upon human $11 \mathrm{fe}$ as 'the will of God,' be it disease, famine, flood, epldemic, poverty, starvation, unemployment, ili1teracy, or feeble-mind edness. (Sanger, 1931:347)

The Cathol1c Church displayed its first overt opposition to contraception at the First National Birth Control Conference; it was far from its last.

In 1920 Margaret and W1lliam Sanger were divoroed. In 1922 Margaret married Noah slee, the founder of the Three-in-one 011 Company. (Douglas, 1970:178) Their marrlage had impact on the movement only through the fact that slee gave financial support to Sanger's efforts.

Sanger's name was becoming increasingly known; by 1921 she was truly an international figure. Her aotivities were discussed from England to Japan. It was the latter that invited her for an official visit in 1921. The Ka1zo (Young Reconstruction League) was hosting a conference 
and wanted Margaret Sanger to address them. Her cospeakers were to be Albert Elnstein. Bertrand Bussell. and H.G. Wells. (Douglas, 1970:164)

The Clinical Research Bureau was founded in New York in 1922 by Sanger. (Douglas, 1970:202) The Bureau was a contraceptive clinic, much like the Brownsville Cinic, though extra attention was given to the necessity of sound research. Another important difference was the employment of staff physiclans. Stringent medical reoords were kept on all patients in hopes of proving the relationship between birth control and health. The clinic functioned smoothly and without difficulty unt1l 1929. In April 1929 the Clinical Research Bureau was ralded and the flles of all patients were conflscated. Sanger complained loudly. Chlef Magistrate McAdoo sald the pollce had indeed exceeded the authority of their warrant by impounding the files, though it was too late to remedy the error. (Douglas, 1970: 295) This incident attracted considerable attention from the medical profession, for the issue of doctor-patient confidentiality was of great import to them. The outcome of the entire incident was a strengthening of the Crane decision, giving physicians the right to dispense contraceptives to "cure and prevent disease."

As progress was being made on the national level in terms of increasing awareness and public support, there was growing dissension within the movement's leadership. 
Sanger held firmly to the belief that new judicial rulings were the best strategy. Others were of the opinion that direct legislative action was needed to overturn the Comstock Law and make birth control totally legal. Th1s rift led to Margaret Sanger's resignation in June 1928 as president of the American Birth Control League. (Douglas, 1970:202) However, she maintained her position on the board and continued editing the Birth Control Beview. In June 1929, following the raid of the Clinlcal Research Bureau, she withdrew from the League completely and surrendered all rights to the Birth Control Review. (Douglas, 1970:203)

In 1931 a bill was introduced that epitomized the rift within the leadership. The bill would repeal the Comstock Law as related to physicians only. Sanger supported this bill, feeling that a wholesale repeal of the Comstock Law would leave the door open for an abundance of quackery in the contraceptive field, at least until a safe and effective contraceptive was developed. Others In the movement, most notably Mary Ware Dennett, urged total repeal of the Comstock Law and did not support the so-called "doctor's b1ll." (Douglas, 1970:215) However, the bill was killed in committee in 1931, 1932, and 1933 and was not introduced again thereafter. (Douglas, 1970:218) In 1942 Planned Parenthood Federation of America evolved from the American Birth Control League, which Sanger 
had founded in 1921. Sanger supported research efforts throughout her career, as does Planned Parenthood now. Her hope was that a safe, effective and inexpensive contraceptive could be developed. Through the financial support of Mrs. Stanley MoCormick, a staunch supporter of birth control, researchers jolned the worcester Foundation for Experimental Blology shortly after World War II. (Douglas, 1970:254) It was from this group that the birth control p1ll emerged as the most effective means of contraception to date. The birth control p1ll was approved for public use and went on the market in 1960. In 1952 the International Planned Parenthood Federation was formed at a population conferenoe in India. (Douglas, 1970:252) In 1953 Margaret Sanger was elected president at the age of seventy-three. (Douglas, 1970:252)

Margaret Sanger d1ed on September 14, 1966, at the age of elghty-seven. An epitaph she wrote in 1936 for her frlend, Havelock Hlis, applies equally well to her:

A great person, a beautiful spirit, a world's work done. What more can one ask of 11fe? Finis. (Douglas, 1970:262)

SOCIAL AND POLITICAL ATRITUDES

A discussion of influential factors is essential to the understanding of any social movement. The areas of politics, religion, economics, and public and professional attitudes all interact throughout the Iife span of the move- 
ment. As noted by W1lliam Bruce Cameron in Modern Soclal Movements, "...the essence of a social movement is change." (1966:8) This "change" is two-edged, the movement is attempting to change some portion of the social order and it is simultaneously experiencing an almost perpetual internal changing prooess. Social movements are dynamic. This dynamism, however, makes it difficult to categorize influential factors according to their importance. The wrlter has nonetheless attempted to organize the various components of the birth control movement in their descending order of significance. It is fully realized that this is a somewhat subjective categorization. though of importance in organizing the data. Criterla for the categorization included the percelved amount of activity within a component for the period under discussion as well as an assessment of the impact of that activity. Soolal and political attitudes are believed to be of paramount importance in the period 1873-1960, and therefore w1Il be discussed first.

Expressed attitudes, including professional, public, and political, underwent considerable change in the years 1873 to 1960 . Horizons broadened and sentiments I1beralized.

Professional Attitudes

The role of the professions, particularly medicine, has been significant in the development of the birth control movement. Examination of the changing posture of this and 
other professions is useful.

The medical profession for many years did not acknowledge the 1mportance of birth control; neither the health nor philosophical rationale held import for them. Dr. John Reynolds, president of the American Gynaecologloal Society. elucldated that group's view in 1890; he warned that they "... should have nothing to do with the nasty business." (St. John-Stevas, 1971:29) Consequently, 1t was many years before the medical profession became involved in the pursuit of a more liberal birth control policy. Dr. Jacob1. in his 1912 presidential address to the American Medical Association, made one of the first positive statements by a physician in favor of contraception. (St. John-Stevas, 1971:20) Th1s was only a first step; the support of the profession was far from achleved. Exemplary of the res18tance to change is the 1918 account of Dr. W1lliam H. Cary; he developed one of the first contraceptive jellies, but was not permitted to publish it in any of the then existent medical journals. (Hard1n, 1964:242)

Dr. Emmett Holt, author of The Care and Feeding of Children, encouraged his fellow physicians as early as 1918 to increase their awareness of birth control. (Douglas, 1970:157) He felt a reliable contracept1ve was 1mperative and established a medical committee to create a researchorlented birth control clinic. Sanger and other leaders in the movement were delighted to see physicians taking 
initiative in this area.

The 1920 s saw increasing recognition of the 1ssue of birth control among professionals. This was accomplished through multiple efforts, one being the activity of the National Birth Control League. The education of physiclans regarding contraception at the First National Birth Control Conference (1921) was an important step in helping medicine recognize 1 ts responsibilities in this area. (Douglas, 1970:160) Th1s sense of responsibllity continued to grow; in 1925 the synecological section of the American Medical Association passed motion recommending judicial modification of existing statutes to allow physiclans to advise patients on contraception. (The People Pack, 1972:96) The impetus for involvement was helghtened in 1929 when Sanger's Clinical Research Bureau was ralded and patient records confiscated. The profession complained vigorously at the infringement of doctor-patient confidentiality. (Douglas, 1970:295) It proved to be a rallying point for medicine.

In 1930 the New York Academy of Medicine stated, "...the public is entitled to expert counsel and information on the important and intimate matter of contraceptive advice." (Douglas, 1970:213)

The movement felt it had gained an ally by 1937, when the American Medical Association unanimously agreed to accept family planning as a requisite in both medical 
education and practice. (The People Pack, 1972:97) The medical profession exerted pressure in Congress, in practice, and in its schools to encourage a liberalization and acceptance of birth control.

In the early 1960s the American Medical Association acknowledged that:

An intelligent recognition of the problems that relate to human reproduction, including the need for population control, is more than a matter of responsible parenthood; it is a matter of responsible medical practice. (The People Pack. 1972:5)

Here again the goal of population stabilization is linked with the birth control movement.

Social work is another profession that has only recently recognized its responsibilities in the area. of birth control. Not unt1l December 1962 did the National Association of Social Workers pass a resolution acknowledging the necessity of social work attention to family planning. (Gray, 1966:97) Provision of referral services, birth control counseling, and increased professional awareness have been more apparent in recent years.

\section{Public Attitudes}

Public opinion has also undergone considerable change in the twentieth century. The early part of the $1900 \mathrm{~s}$ saw birth control as something not discussed by "nice" people. It was considered a nasty and unspeakable subject. The Comstock Law of 1873 reinforced this view. 
Margaret Sanger was one of the first people to make a concerted effort to awaken the public to the respectability and urgency of the birth control 1ssue. Emily Taft. Douglas, Sanger's blographer, wrote about her subject's concern for public awareness of birth control. In Sanger's book, Woman and the New Race, Douglas paraphrases her sentiments :

...man alone had been given the power to perfect his race by promoting quality instead of quantity....since any code of human rights assumes that the individual controls his own person. it was high time that women gained that basic freedom. (Douglas, 1970:138)

As public sentiment began to percelve birth control as a respectable subject, organizations began endorsing 1t. In 1930 the National Council of Jew1sh Women and the General Federation of Women's Clubs both endorsed the birth control movement. (Douglas, 1970:213) This was the beginning of the legitimization of birth control. An escalation of support and public endorsement followed. Th1s increasing support was essential to the development of the birth control movement, as it is for any social movement. It has been noted that,

For a movement to begin and gain impetus, it is necessary for people to be jarred loose from their customary ways of thinking and belleving, and to have aroused within them new impulses and wishes. (Mclaughlin, 1969:13)

Th1s "Jarring loose" phenomenon was beginning to occur in America. 
The first large scale study on attitudes and practices concerning birth control was jointly conducted in 1941 by the Soripps Foundation for Research in Population Problems and the Mllbank Memorlal Fund. (Jaffe, 1973b: 17) Their findings indicated that the majority of white protestants were using some form of contraception in 1941. (Jaffe, 1973b:17) It was considerably later before the government of the United States reflected this public sentiment; a lag that history indicates is common, if not inevitable.

Another study done in 1943, with a sample of women 20 to 35 years of age, found that 84.9 percent of them favored contraception for married women. (Fletcher. $1954: 245$ )

The impact of the Comstock Law on public attitudes should not be overlooked. These statutes confirmed, in the American mind, that birth control was an obscene, dirty, and unspeakable subject. In 1935 NBC finally ended its radio ban on the subject of birth control. (Westoff, 1968:307) However, this attitude persisted and is graphically illustrated by the fact that it was 1955 before a national magazine published an article specifically naming methods of contraception; it was 1959 before the subject was mentioned in a television broadcast. (Jaffe. 1973b:18) It is surprising that the media showed such poor comprehension of public interest in, and utilization of, birth control services. 
A utilization and attitude study that was conducted in 1960 revealed that 80 percent of all American females favored birth control in general; only 13 percent favored only the rhythm method. (Westoff, 1968:59). It was in this year, 1960, that the birth control pill was placed on the market. This technological advance was a turning point in the movement and from this point on the picture of birth control in America changed rapidly.

Social Organizations

The activities of social organizations, particularly those directiy related to the birth control movement, had perhaps a greater 1mpact on attitudes and awareness during this period than any other single factor.

In 1914 Margaret Sanger helped form the National Birth Control Ieague and publication of the Birth Control Review began shortly thereafter. As mentioned earlier, this publication was the movement's inftial means of communication with supporters tnroughout the country.

The Committee of one Hundred was also organized in 1917 by Jullet Rublee, the wife of an attorney with the Federal Trade Commission. (Douglas, 1970:111) The organization was composed of upper-class women whose goal was the emancipation of poor mothers. It is not uncommon, according to social movement theory; to find middle-class groups bonding. together to assist a less powerful group. (McLaughlin, 1969:22). The Committee of one Hundred is 
exemplary of this. They hoped to accomplish their goal by funding Sanger's defense on the Brownsville Clinic charges, as well as educating the public. They felt education of the public regarding the movement's goals was particulariy important, especially for the poor. Agaln, the Commlttee was reflective of social movement theory:

Astute leaders and observers of social movements have stressed the importance of the disciplined minority, both as a form for the total movement and as a 'hard core' which educates, mobilizes, and directs the 'masses' of the larger movement..." (Cameron, 1966:15)

Following the Brownsville Clinic ralds the charge of genocide was ralsed, though interestingly, not by anyone in the nelghborhood served by the clinic. The charge was supposedly based on the fact that the clinlc was located in a largely Jewish neighborhood. (Douglas, 1970:112) Sanger termed such an accusation as utterly fantast1c. The charge of genocide has continued to be tied to the birth control movement on an on-again, offagain basis by some minority groups. The black militant group has most frequently been verbal in this regard. Generally, the charges result from an effort by the white community to substitute birth control for economic development. (Westoff, 1973:171) Government is finally recognizing that birth control is only one small part of the multifaceted programs that are needed. It is generally accepted, however, that the majority of the black community 
accept birth control programs for their intended purpose, a chance for personal cholce in the matter of fertility. According to Charles Westoff, Assoclate Director of the Office of Population Research and former executive director of the Commission on Population Growth and the American Future:

The picture of black attitudes 1s... diverse, ranging from indifference to animosity. In the black population at large, however, the average person, especially the woman, is just as anxious to regulate her childbearing as is her white counterpart. (1973:171)

Returning to the development and 1mpact of social organizations, it has been noted that the American Birth Control League was founded and directed by Margaret Sanger in 1921. following a leadership rift within the movement. The rift was based on strategy of change; Sanger wanted new rulings on standing statutes while others held fast for repeal of old and passage of new legislation.

Planned Parenthood Federation of America was founded in 1942 as a result of the merger of the American Birth Control League and the Clinical Research Bureau. (Plotrow, 1973:16)

Birth control activists and professional groups continued to work together, if somewhat disjointedly. Areas of most concern during the 1940 s and 1950 s were professional skills related to birth control, 1mproved 
scientific technology, public awareness, federal expenditures (which were insignificant at this point), and improved leadership and governmental priorities. (Plotrow, 1973:19) The health care rationale for birth control also gained considerable credence during this period.

The population control advocates were also active during this period; increasing attention was given to expanding population and shrinking resources; public awareness of these issues increased.

International Planned Parenthood was founded by Nargaret Sanger, then in her sevent1es, and Lady Rama Rau of India at an international meeting in 1952. (Westoff. 1968:307) This was the first organizational step toward making the movement world wide. Population growth rates had more influence in involving many underdeveloped nations than did the individual rights arguments.

Perhaps the overall goal of the social organizations of this perlod is summed up by Dr. Alan Guttmacher, former President of Planned Parenthood Federation of America:

We in leadership must replace mysticism and ignorance in human sexuality by complete knowledge. It should be done at high school levels and I think it must be done at college levels. The thing we have to do is equip young people with a sense of what I call responsible sexual behavior and that means that on every occasion in which sex is practiced - in or out of marriage - unless there is urgent desire to produce a child. the most effective contraception available should be used. The young people want to learn. They want to be sexually responsible. (The People Pack, 1972:50) 
Political Attitudes

The political atmosphere of the early twentieth century was partially determined by the executive branch of the government. Early in his career, President Theodore Roosevelt (1859-1918) made a statement opposing birth control in Metropolitan Magazine. He warned the nation

...against 'race sulcide' and the 'w1llful

sterility' that 'inevitably produces and accentuates every hideous form of v1ce.' (St. John-Stevas, 1971:20)

This tone of disapproval on the part of the government was to pervade its activities until past the middle of the century.

Groups that had political influence, though not directly affiliated with the government, encouraged more liberal consideration of the subject. The Industrial Workers of the World (IWW) provide an excellent example. W1lliam D. Haywood, a leader of the IWW, recognized as early as 1912 the economic significance of birth control because 1 t was directly related to union members and their large families. Haywood became acquainted with Margaret Sanger early in her career and encouraged her to organize her activities. He gave her the names of organizers in the silk, woolen, and copper industries and offered his assistance in getting contraceptive information to the working men and their wives. (Sanger, 1931:61) This assistance was invaluable. It was Haywood's IW' supporters who, in 1914, assisted in the release and 
distribution of Sanger's pamphlet, Family Limitation. (Sanger, 1931:61) Throughout the course of 1ts existence, the IWW offered the birth control movement moral support, strategic advice, and practical services.

The Syndicalists were another politically oriented group (considered among the radical element with the IWW) active during this period. This organization was particularly significant in Europe. The Syndicalists in France had advocated birth control for many years and issued pamphlets and books to educate the public. (Sanger, 1931:68) It is significant that the labor organizations, those in close communication with the working public and its problems, were the first politically influential groups to support birth control.

The years 1914-1915 saw birth control advocates endeavoring to increase political awareness. The NeoMalthusian League in England, led by Dr. Charles Drysdale, offered considerable moral support and public encouragement to the movement in America. However, he indicated they would not actively participate in America's struggle, but that this nation should "fight its own battles." (Sanger, 1931:98)

The National Birth Control League was founded in 1915 by Margaret Sanger, its purpose being both communication and political 1nvolvement. (Sanger, 1931:124) The stated goal was to change laws in an "...orderly and proper 
manner." (Sanger, 1931:125) It was within this organ1zation that the aforementioned rift in leadership occurred in 1921. Mary Ware Dennett, presiding over the League, felt they could not support Sanger because she had broken the law. Additionally, Sanger's strategy was at varlance with others in the League's administration; they wanted total repeal of the Comstock Law and new, more liberal. legislation passed. Sanger insisted that new rulings on old statutes would be more successful in achieving change. The National Birth Control League continued to have influence and be active following sanger's withdrawal. However, Sanger's charisma was an important factor in gaining supporters and holding the movement together; her resignation from the League in no way impaired her strong Individual leadership within the movement. The importance of Individual leaders within any social movement, particularly in its early stages, is indisputable. It has been noted that "...their example helps to develop sensitivities, arouse hope, and break down resistances." (Mclaughlin, $1969: 10)$

The Roaring Twenties in this nation witnessed considerable political mobilization by birth control advocates. In their activities, however, they falled to persuade one politically active group to join them. The Socialist Party maintained that any reforn that "...dulled the edge of poverty retarded the main goal, the fall of 
cap1tal1sm." (Douglas, 1970:154) The party felt that birth control would indirectly affect poverty and consequently, they refused to endorse it. other activities overshadowed the lack of Soclalist support.

Sanger helped found the Amerlcan B1rth Control League on November 10, 1921, following her break with the National Birth Control League. (Sanger, 1931:212) The new League was legitimized when it was incorporated under the membership laws of the State of New York.

The international aspects of the birth control movement also grew during the twenties. This facilitated increased public awareness as well as some pressure on the federal government to recognize the importance of the 1ssue. It is imperative for the survival of any social movement that their issues be recognized as important and of general societal significance.

Iondon hosted the Fifth Neo-Malthusian and Birth Control Conference in 1922. (Douglas, 1970:177) International conferences were abundant from this point forward. The Population Union grew out of the Sixth International Conference on Birth Control which was held in Geneva, Switzerland, in 1926. (Douglas, 1970:197) Th1s was the only international group producing research studies, bulletins and conferences on related subjects for many years. The First World Population Conference convened in Geneva in 1927. (Douglas, 1970:301) 
Not all aspects of the international scene supported birth control, however. It has long been known that nations often equate declining population with declining power; this was the situation in post-war Europe in the early 1920s. Many European governments were urging high birth rates in order to counteract their wartime population loss. (Sanger, 1931:279). The professional community, however, persistently emphasized the importance of birth control.

The New York League of Women Voters ut1lized political pressure in 1927 and urged repeal of the Comstock Law. (Douglas, 1970:200) The twenties awakened many such organizations to their social responsibility regarding birth control; as public awareness grew, more political pressure was exerted encouraging repeal and changes in the statutes. Government, however, continued to harass birth control advocates and indirectly publicize their activities; as noted by the New York World in 1921:

The effort to muzzle the birth control propagandists is as stupid an attempt at obstruction as ever helped a minority movement. It is a puzzle to see how anyone can Imagine that police abuses, star chamber sessions, inquisitorial investigations, false arrests, farcical persecutions, dummy complaints... will suppress the advocates.... The score today is all in favor of the birth control advocates, not because of the excellence of their case, but because of the sheer stupidity of the opposition. (Douglas, 1970:162)

The American Medical Association first expressed a change in 1ts attitude toward birth control in 1925. At 
that time the gynecological section of the AMA recommended a change in the laws to allow physicians to dispense birth control information. (St. John-Stevas, 1960:11) The American Medical Association spoke out again in 1937 when the membership unanimously agreed to accept birth control as "...an integral part of medical practice and education." (st. John-Stevas, $1960: 11$ )

International headlines concerning birth control again reached the public in 1930. During that year 130 scientists and clinic directors met in Zurich for the Seventh Intermational Birth Control Conference. (Sanger, $1931: 341$ ) It was also in 1930 that Margaret sanger V1sited the USSR. She brought back lengthy commentaries on the state of birth control in that nation; says her blographer, E.T. Douglas, of what she found:

Those in need could have a skilled, cheap, rapid curettage at one of the large abortoriums run with the precision of an assembly line. More basic, all dispensaries and gynecological clinics throughout the nation gave regular birth control instruction, publicized by posters, exhibits, flims, and pamphlets. (1970:211)

Undoubtedly the United States govermment was a bit chagrined to be compared in a negative light to a Communist nation. However, the position of the government did not change. Government disapproval often prevented publicity or accurate reporting even when contraceptive services were avallable. Congress virtually ignored the subject. (P1otrow, 1973:31) 
The govermment finally made a token gesture in 1938 when President Franklin D. Roosevelt appointed a committee to study population problems through the National Resources Committee. (Westoff, 1973:163) Their report was titled "The Problems of a Changing Population" and they concluded that "...transition from an increasing to a stationary or decreasing population may on the whole be beneficlal to the I1fe of the nation." (Westoff, 1973:163) It is here that government began to listen to the arguments of the population control advocates. Their awareness of the irreplacablilty of some resources, as well as a finite food supply the earth can offer, increased along with government's realization of the imperativeness of dealing with the situation. Interest in the health and welfare rationale regarding individual choices also began to increase at this time.

The first official statement in the twentieth century regarding birth control was made in 1942 by the Surgeon General. (Rosoff, 1973:9) He allowed states to pay for birth control services from federal funds provided through Maternal and Child Health allottments. (Rosoff, 1973:9) The public was not to hear from the government again until late in the 1960s.

Concerns with population growth continued to gain public airing. The Cheltenham Conference on Population and World Resources in Relation to the Family, held in 
1948, brought the discussion to the forefront. (Douglas. 1970:245) Many of the nations represented at the conference felt effective birth control was one way of achieving population stabilization. The international scene, more than any other, drew together the two parallel movements of population control and voluntary utilization of birth control. Population stabilization was sought through utilization of effective contraception.

It was at this conference that sir John Boyd orr of the United Nations Food and Agriculture organization stated that birth control had a permanent place in international affairs; he predicted the formation of an international association. (Douglas, 1970:245) The pressure exerted by both national and international associations concerned with population growth had considerable influence on govermmental attitudes during this period.

The first step toward mobilizing professionals concerned with birth control occurred in 1952. The National Academy of Sciences sponsored the formation of the Population Council in November of that year. (Corsa, 1966:260) This was a private foundation concerned with funding and encouraging research endeavors in the fleld of population. John D. Rockefeller III was the first chairman of the board. (P1otrow, 1973:13)

These developments perhaps sound misleadingly optimistic. The government of the 1950 s maintained many 
of the old attitudes which regarded birth control as 1llegal and immoral. On the other hand, the public ind 1cated in many ways its support and utilization of contraception. An excellent example of government's negative attitude during this decade is found in a December 3, 1959, speech by President Dwight Elsenhower:

I cannot imagine anything more emphatically a subject that is not a proper political or governmental activity or function or responsib1lity.... This government will not...as long as I am here, have a positive political doctrine in 1 ts program that has to do with this business of birth control. That's not our business. (Hardin, 1964:248)

A clearer statement of governmental sentiment at the time is not avallable. This "...public policy stigmatized contraceptive practice and created obstacles to obtaining medical contraception," even for those who wanted 1 t. (Jaffe, 1973b:18)

Though he was strongly opposed to a birth control policy in this country, President Eisenhower did appoint a commission that ultimately commented on the population problem. In 1959 he requested a report from The President's Committee to Study the United States Military Assistance Program. (P1otrow, 1973:36) The committee later became known as the Draper Committee, after 1ts cha1rman, W1lliam H. Draper, Jr. The committee found it was impossible to deal with forelgn ald without considering population. Thus, in July 1959, when the Draper Committee 1ssued 1ts report, Draper stated, "The population problem... 
is the greatest bar to our whole economic ald program and to the progress of the world." (Plotrow, 1973:36) The committee recommended that when ald-recelving nations requested 1t, help should be given in dealing with rapid population growth. (St. John-Stevas, 1971:28) This help was to take the form of establishing health clinics that would provide contraception, sterilization, and some abortion services. This recommendation was extremely important in changing the political atmosphere and ultimately faclilating a change in legislated policy on a domestic level.

The Roman Cathol1c bishops in November 1959 prepared a response to the Draper Committee's recommendations. Not surprisingly, it was disapproving. The bishops stated that the Draper recommendation was a "...morally, humanly. psychologically, and politically disastrous approach to the population problem." (St. John-Stevas, 1971:28)

Politically, then, the first half of the twentieth century was important in setting the mood for the changes that developed in the 1960s. A gradual realization of the respectability and importance of birth control permeated the public, the professions, and the government. A major turning point in the awakening of govermment to public sentiment occurred in New York City in 1958. A demonstration was held to encourage reversal of the ban on contraceptive prescription in the c1ty hospitals. The 
turnout was so tremendous that it was a strong indicator to government of positive public sentiment. (Jaffe, $1973 \mathrm{~b}: 18)$

The groundwork for policy formation and implementation was done. Technological advances (the birth control pill and intrauterine device), the impact of the Draper Committee, and the election of John F. Kennedy to the presidency all signaled 1960 as the beginning of a new era. This era has been a period of blossoming of the birth control movement in this country. The period beginning in 1960 will be dealt with in the next chapter of this thesis.

\section{RELIGIOUS INFLUENCES}

The religious influence on the development of the birth control movement in this country has been considerable. A brief survey of official Catholic and Protestant church positions w1ll give a clearer picture of what this influence has been.

For centuries Christian doctrine stated that the primary aim of intercourse was procreation. Any artificial interference was considered against the "laws of God." St. Augustine of Hippo wrote:

Sexual intercourse even with a lawful wife is unlawful and shameful, if the of spring of ch1ldren is prevented. (Hardin, 1964:214)

This position was not altered and in the nineteenth century 
churches reiterated the traditional doctrines.

It has been stated that Christian rejection of contraception was related to the rejection of the lax sexual s.tandards of the Roman Empire. (St. John-Stevas, 1971:14) They did not want to accept any part of that culture, though contraceptive techniques were known and practiced at the time. Their hostility toward the decadent behavior of the Romans left no room for compromise.

The Cathol1c Church from early in its history has frowned on intercourse, even in the marriage bed. Pope Gregory, A.D. 590-604, advised married couples to have intercourse only for the purpose of procreation. (Westoff. 1968:168) He went on to state that if any pleasure was derived by either partner in the intercourse, even if. their purpose was procreation, they had transgressed the law of marriage. (Westoff, 1968:168)

Pope Gregory IX set down decrees in 1230 that were laws of the Cathol1c Church until 1915; these decrees related to "Voluntary or Chance Homlclde." He stated:

If anyone to satisfy his lust or in meditated hatred does something to a man or woman or gives something to drink so that he cannot generate, or she concelve, or offspring be born, let him be held a homlclde. (Westoff, 1968:169)

The Roman Catholic argument against mechanical and chemical forms of contraception as "unnatural" and the association of "unnatural" with "evil" originates in the writings of a third century theologin, Tertulilan, ca. 
A.D. 160-230. (Hardin, 1964:181) Tertullian wrote:

What God was unwilling to produce ought

not to be produced. Those things therefore

are not best by nature which are not from

God, the Author of Nature. Consequently.

they must be understood to be from the Devil,

the disturber of nature; for what is not

God's must necessarily be his rivals.

(Hardin, 1964:183)

These attitudes and doctrines have remained essentially unchanged in the catholic helrarchy even into the twentieth century.

Some authorities feel that contraception had little significance within the Church until the discovery of efficient contraceptives gave it a reason to exist. (Sulloway, 1959:40) It is noted that the Catholic Encyclopedia 1907 does not include the topic "Birth Control." (Sulloway, 1959:45)

The first overt opposition of the Catholic Church to the birth control movement came in 1916 in St. Louls. Nargaret Sanger had arranged a rally at the Victoria Theatre following the First National Birth Control Conference; over 2,000 persons were walting to enter when Sanger and her entourage arrived. The manager of the theatre had been threatened w1th a permanent cathol1c boycott if the rally was allowed to be held; the doors were barred. (Douglas, 1970:97) This was the first overt opposition the Catholic Church exhibited in this country. The Catholic population of the United States was given a slight reprieve by the Church when, in 1930, the 
rhythm method was accepted as a natural means of birth control. (Hardin, 1964:228) Two physicians, Dr. K. Ogino in Japan and Dr. H. Knaus at the University of Prague gave the method scientific validity in that year. (Hardin, $1964: 228$ )

The Church was trying mightily to sway public opinion against birth control; they felt it an evil that would lead many away from the "true path" of the Church. However, their efforts may have achleved the opposite of what the strategists planned. On July. 5. 1930. in The New Yorker, Helena Huntington wrote:

...the birth control question has looked 1ike a personal encounter between Margaret Sanger and the Catholic Church. One might ask, however, whether the Roman hierarchy has not after all been her best friend. Several times its blundering opposition has focused public attention on the birth control movement which was not ingenious enough to do so for itself.... (Douglas. 1970:209)

In spite of 1ts "blundering," the Church continued 1ts efforts. In 1938 Cathol1c opposition remained strong; Father Joseph Vaughn said on a Los Angeles radio broadcast. "Better a baptized ldiot than a child unborn." (Douglas, 1970:238) Several Massachusetts papers recelved anonymous letters during this year attacking sanger as "...the chief proponent of the subversive doctrine undermining American virility." (Douglas, 1970:238) Pressure was not 11mited to the mass media. The New Haven Board of Education and the Holyoke Congregational Church in 1938 both cancelled 
speaking engagements by Margaret Sanger after considerable Cathol1c pressure. (Douglas, 1970:238)

Catholic pressure extended beyond the United States. In 1946 Shidzue Kato, a Social Democrat in the Japanese Diet and head of Japan's Family Planning Association, invited Sanger to Japan. She was denied an entry visa by General Douglas MacArthur. According to one Tokyo newspaper:

In view of the pressure of the Catholic Church groups, it was believed impossible for General MacArthur to allow her (Mrs. Sanger) to lecture to Japanese audiences without appearing to subscribe to her views. (Douglas, 1970:247)

What is interesting in this particular incident is that Japan had only 130,000 Catholics in a population of more than $80,000,000$. (Douglas, 1970:247)

The Catholic position did not vary during the perlod 1873-1960. It was adamantly against blrth control.

The Protestant stand appeared more flexible. The first public support by a Christian minister for birth control came from England. An American pastor, Moncure Conway, was speaking at the South Place Chapel in London in 1878. He denounced the prosecution of Besant and Bradlaugh and was supportive of some alms of the NeoMalthusian League. (Hardin, 1964:217)

As early as 1913 endorsements were being given. Reverend W.F. Lof thouse, a spokesman for the Methodist Church, was giving evidence at the National Birth Rate 
Commission in London; he said he would allow mechanical contraception if "moral restraint" was not possible. (Hardin, 1964:219)

The Unitarians were the first religlous group to support birth control; they issued a statement of endorsement in 1930. (Douglas, 1970:213) The Anglican bishops at the Lambeth Conference followed shortly thereafter. The Federal Council of Churches of Christ in 1931 published a report favoring birth control. (St. John-Stevas, 1960:11) other religlous groups began endorsing birth control in that year, including the Presbyterians, Universalists, Methodists, and the Central Conference of American Rabbis. (Douglas, 1970:213) The Anglican B1shops issued the following statement regarding birth control on August 15. 1930 :

Where there is a clearly felt moral obligation to limit or avold parenthood, the method must be decided on Christian principles. The primary and obvious method is complete abstinence from intercourse so far as may be necessary in a iffe of discipline and self control. Nevertheless, in those cases where there is such a clearly felt moral obl1gation to limit or avoid parenthood and where there is a morally sound reason for avolding complete abstinence, the conference agrees that other methods may be used, provided this is done in the light of the same Christian principles.

The wave of Protestant support continued to grow and birth control became increasingly acceptable and respectable in church circles. The benefit this gave the 
birth control movement is difficult to assess, though it was unquestionably significant.

\section{JUDICIAL INFLUENCES}

The impact of the judiciary on the birth control movement and policy development has been considerable. As mentioned earlier, the strategy of the birth control activists was utilization of the courts as a debate forum to win more liberal interpretations of the statutes. That is essentially what happened. Judicial action brought the first changes in federal attitude. As interpretations were broadened the public became more vocal, awareness Increased, and gradually acceptance came to the area of contraception.

A review of the major judicial decisions related to birth control would be helpful in putting the role of the judiclary in perspective.

The first major decision affecting contraception came in 1918. In that year Judge Frederick E. Crane of the New York State Supreme Court, Appellate Division, heard a case concerming Section 1142 of the Penal Code. (Douglas, 1970:135) This section stated that no one could give birth control information for any reason. However, Section 1145 provided some flexiblilty by allowing physicians to prescribe contraceptives for the cure or prevention of disease, particularly venereal disease. 
(Douglas, 1970:101) Judge Crane stated in his decision that a licensed physician could give contraceptive advice "...for the cure and prevention of disease." He used Webster's then current definition of disease, "...any change in the state of the body which caused or threatened pain and sickness." (Douglas, 1970:135) By this definition unwanted pregnancy, the threat of abortion, and maternal complications could be called conditions threatening pain and sickness. This decision allowed the law to be stretched beyond 1ts original intent; the birth control activists considered it an essential first step. Davis vs. U.S. was heard by the Supreme Court in 1933. The decision in this case established that intent. to use contraceptive articles for lilegal purposes was necessary for a conviction under the postal and transport statutes; this allowed manufacturers of contraceptive products to distribute them to physicians. (st. JohnStevas, 1960:17)

Shortly following this decision came United States vs. One Package in 1934. The case was initially heard by Judge Grover Moscowitz of the Federal District Court of Southern New York. (Douglas, 1970:221). The sult concerned the selzure of a package of diaphragms (vaginal pessaries) addressed to Dr. Hannah Stone, which allegediy violated Section 305 of the Revenue Act. Dr. Stone was employed by the Clinical Research Bureau at the time this occurred. 
This act barred importation of all goods for use as contraceptives. (Douglas, 1970:221) Judge Moscowitz stated, "We cannot assume that Congress intended to interfere with doctors prescribing for the health of the people." (Douglas, 1970:221) The government appealed the decision and. Judge Augustus N. Hand of the Circuit Court of Appeals upheld the opinion of Judge Moscowitz. He stated concerning the law:

Its design, in our opinion, was not to prevent the importation, sale or carriage by mail of things which might inteli1gently be employed by conscientious and competent physicians for the purpose of saving life. or promoting the well-being of their patients. (Douglas, 1970:221)

Judge Hand's decision removed the last legal barriers to the dispersion of contraceptive information to physicians and other qualified persons; it opened up the malls for the first time since the passage of the Comstock Law. By the late 1930s most federal statutes were being interpreted so that "...contraceptives intended for bona fide medical use, for the treatment or prevention of disease, and contraceptive books and pamphlets which are not written in obscene language..." could be imported, transported, and malled without legal harassment. (St. John-Stevas, $1960: 18$ )

The judiciary entered a period of relative inactivity concerning birth control following this decision. However. In the late 1950s questions of constitutionality arose concerning federal and state statutes regulating birth 
control. (St. John-Stevas, 1960:23) Many felt that these laws denied the individual right to pursuit of happiness and also violated the due process rights protected by the Fourteenth Amendment. The debate regarding constitutionality continued into the 1960 s.

In May 1959 the question of constitutionality came before a New Jersey judge. He declared that the state statute banning sale and distribution of contraceptives was unconstitutional. (St. John-Stevas, 1960:23) This decision marked the beginning of more activity in the United States judiciary regarding contraception.

Griswold and Buxton vs. Connecticut was heard by the United States Supreme Court on June 7, 1965. (Douglas, 1970:261) The case concerned the Connecticut law of 1879 which stated:

Any person who shall use any drug, medicinal article or instrument for the purpose of preventing conception shall be fined not less than 50 dollars or imprisoned not less than 60 days nor more than one year or be both fined and 1mprisoned. (st. John-Stevas, 1971:49)

The majority opinion was that the Connecticut law making use of contraceptives illegal was unconstitutional in that it violated the right to privacy. (Douglas, 1970:261) This decision moved birth control out of the legal arena and into the realm of personal cholce and freedom. (Corsa, $1966: 260$ )

The New Jersey Supreme Court heard State vs. Baird 
in 1967. The ruling held that the New Jersey law banning explanation and display of birth control devices was a violation of the First Amendment of the Constitution. (Westoff, 1968:308)

In 1970 the Supreme Court declared that Massachusetts' 125 year old law prohibiting the prescription of contraceptives to unmarried persons was unconstitutional. (Westoff, $1968: 49$ )

The same year that the Massachusetts statute fell, 1970, Congress was taking affirmative action of 1 ts own; the Comstock Law was finally repealed. (The People Pack, 1972:103) This removed the only remaining federal restriction concerning contraception. Birth control was finally out of the half-shadow of illegality that had plagued it since its beginnings in this nation. The United States Supreme Court in 1972 made another move toward establishing birth control as an accepted practice within our society. The majority opinion stated that unmarried persons have the constitutional right to practice contraception free of state interference. (Jaffe, 1974:166)

It can be seen that the judiciary, through a series of favorable judgments, helped birth control overcome the burden of illegality placed on it by the Comstock Law. The impact this had on increasing favorable public opinion, encouraging authorization and funding of birth control 
projects, and enhancing utilization of contraception is difficult to assess. However, it is unassailable that the effect was favorable in all spheres.

\section{ECONOMIC ISSUES}

The economic issues surrounding birth control during the period 1873 to 1960 were negligible. Governmental involvement was essentially nonexistent; economic involvement definitely did not become part of the picture until well into the 1960s. By economic involvement, or the economic realm, the writer is referring to the funding patterns of government regarding birth control services and dialogue concerning the relationship between poverty and family planning. Also included in the economic realm are those private organizations that financially assisted the movement.

The poverty 1ssue, which was to gain a major focus In the 1960s and even more so in the 1970s, did not appear significantly during this period.

Several private foundations were the major funding sources for projects that were being operated during the mid-twentieth century. They were particularly interested in professional and scientific research in the area of population growth. The Scripps Foundation for the Study of Population, founded in 1922, was a major contributor to research projects and endeavors. (Plotrow, 1973:8) The 
Milbank Memorial Fund also actively participated in the funding and sponsorship of many endeavors; in 1936 they provided the financing for the office of Population Research at Princeton University, under Frank Notestein's direction. (P1otrow, 1973:8)

Economic issues did not achleve the 1mportance they hold today until the last two decades. Their impact and influences will be discussed later. 
CHAPTER $V$

1960-1975: GROWTH OF THE MOVEMENT

POLITICAL DEVELOPMENTS

Political activity (executive, legislative, and judicial) in the present era has been a major instrument in legitimizing the birth control movement. Changing attitudes within the executive branch are a ready indicator of shifts in the political arena of the 1960s. President Dwight D. Elsenhower stated toward the end of his term that he felt birth control was definitely not the government's business. John F. Kennedy did not encourage government agencies to participate in the birth control effort; however, he did not oppose the initiative of others in his administration who were interested in this issue. (Piotrow, 1973:227) Perhaps in part this lenlency was compensation for criticism of his Catholicism and presumed anti-birth control stand.

Lyndon B. Johnson was the first president supporting federal governments involvement with birth control; he felt the subject was relevant, important, and deserved the public's attention. (Plotrow, 1973:227) Johnson utilized the prestige of the presidency to bring more awareness to the issue, though he was reluctant to take the initiative 
in program development.

Richard M. Nixon, during his term in office, was also supportive regarding government involvement with birth control. He urged funding from Congress and more efforts at program development.

Changes in executive positions lagged behind public opinion. Public support for birth control had long been present, though the administration's perception of that support was slow. Washington has traditionally been slow to recognize public attitudes, on this and other issues. (Piotrow, 1973:222) As Frederick Jaffe noted,

The change of policy did not transform the U.S. from a nation in which contraception was rarely practiced to one in which it is widespread; it has been widespread for a long time. (1973b:17)

The health rationale was of the utmost importance during the period of changing administration attitudes. This was pointed out by Jaffe, "...the federal program has been advanced, not for population control, but to improve health and reduce the impact of poverty and deprivation." (Harkavy, 1969:368) Government was maintaining a micro, or individual, perspective.

Government's recognition of the need for birth control services prompted slowly changing priorities. Dissemination of birth control information and services within a society is usually a result of that society's priorities regarding the prevention of unwanted pregnancies in terms 
of health, social, and economic values. (Jaffe, 1973b:17) The general direction of government in the 1960s was provision of effective contraceptive information and services to all in this nation who wanted or needed 1 t. (Harkavy, 1969:373) The emphasis on education, services, and their relation to general health status strengthened the position of those advocating individual rights. The affiliation of birth control services and the health care professions was cemented during the 1960s. The government's recognition of its responsibility regarding health care led to the incorporation of birth control services into this system. (P1otrow. 1973:233) As historlans have noted, however, the recognition of the need for change and the actual implementation of new programs are of ten considerably separated in time. (Jaffe, 1966:1) Such was the case with birth control in the early 1960s. A very significant technological advance in the beginning of that decade did much to moblilze the implementation of programs. The birth control p1ll was approved for use by the United States Food and Drug Administration on May 20,1960. (Westoff, 1968:91) The pill was to become the mainstay of contraception in this country (followed by the IUD); 1ts effectiveness far surpassed anything previously avallable.

Developments were occurring simultaneously in politically active organizations. In 1960 the American 
Medical Association recommended that all medical students be taught birth control methods in order that they utilize the information in clinic settings. (St. JohnStevas, 1960:27) In the same year the American Public Health Association stated that they considered the population problem a public responsibility. (Corsa, 1966:261) The birth control movement continued to be viewed as at least one mechanism for achieving population stabilization. The American Assembly in 1963 called for local, state and federal governments to take responsibility for making birth control information avallable to all who desired it. (Corsa, 1966:261) The exertion of pressures such as this no doubt hastened the implementation of policy and the formation of programs to administer it.

President Kennedy indirectly provided a political mood that was advantageous to the birth control movement. He was an activist on many social issues, other than birth control, and he brought enthusiasm and direction to the administration. One of the first. steps toward establishing a national policy occurred during his tenure. George McGhee, who had served on the Draper Committee, circulated a report of the Policy Planning Council to members of the administration and Congress in 1961. This report stated that population control was the single most potent influence on economic development, both in this country and abroad. (P1otrow, 1973:56) one of the main recommendations from 
the Council in this regard was expansion of research in population at the National Institute of Health. (Piotrow, 1973:56) The emphasis on the need for research was important in bringing the professional and activist camps together. There was unanimous agreement that research was essential and that better methods of contraception were needed. This agreement regarding research gave the professional community, the birth control activists and the population control advocates a united front with which to exert pressure for change. Th1s was the major area of consensus for these groups at any single point during the movement.

The year 1962 saw significant developments regarding birth control. Planned Parenthood Federation of America merged with the World Population Emergency Campalgn to form Planned Parenthood-World Population. This allowed for a concerted effort in raising public awareness and promoting positive legislation. It also further aligned the birth control movement with the goal of population stabilization. Indicative of the importance of such politically oriented groups was their impact on the funding of the first family planning project in this country. Congress, in 1962, approved the first famlly planning program for Washington, D.C. health clinics, appropriating $\$ 25,000$ for 1ts implementation. (Piotrow, 1973:119) As mentioned earlier, this caused considerable upset among the Catholic 
clergy of the District of Columbia.

The population problem, as well as the health

rationale, continued to arrest the attention of many in government. Secretary of State Dean Rusk was quoted as follows in the New York Times of April 27, 1962:

For us to be indifferent to population factors would be, I think, reckless on our part and we do take very serlously the population trends, the impact of population growth upon development plans and we shall continue to follow that problem. (Piotrow, 1973:58)

Dean Rusk later met w1th representatives from thirty private foundations to discuss the possibility of government and foundation cooperation in researching the population problem. This was significant in that it illustrated the beginning of government-private sector cooperation in dealing with birth control. Population control advocates were pleased to see government recognition of the need for population stabilization. The hope at this point was that this issue would be a major factor in formulating policy.

The United Nations also played an important role in the birth control debate in the United States in 1962. During that year the United Nations endorsed birth control and became an international forum for the discussion of the issue. This forum led to a-significant shift in U.S. orientation. Richard Gardner, a representative of President Kennedy's Task Force on Foreign Assistance, gave a speech 
at the U.N. in 1962 proclaiming U.S. support for international birth control efforts; he perhaps gave more enthusiastic and positive support for such programs than had actually jelled at the time. According to Phyllis Tilson Plotrow, author of World Population Crisis: The United States Response.

.... it was Gardner's speech at the United Nations...that seemed to pull both government and public opinion toward a new policy consensus much more effectively than did the quiet off-the-record discussions that had occupied the previous two years. (1973:67)

This verbal support of foreign birth control programs was considered by many to be implicit support of domestic birth control programs.

The tide of support and public pronouncements continued into 1963. Setting the trend of that year was a speech by former President Dwight D. Elsenhower, who was serving on the Sponsor's Counc1l of Planned Parenthoodworld Population:

- once as President, I thought and said that birth control was not the business of our federal government. The facts changed my mind... I have come to believe that the population explosion is the world's most critical problem. In some areas it is smothering economic growth; 1t can threaten world peace. Millions of parents in our country - hundreds of millions abroad are still denied the clear human right of choosing the number of children they will have. Governments must act and private citizens must cooperate urgently through voluntary means to secure this right for all peoples. Fallure would limit the expectations of future generations to abject poverty and suffering and bring down upon us history's condemnation. (Douglas, 1970:259) 
The population and birth control movements, though with different methods for achleving the common good, had drawn together scientific and religious bodies with their various arguments and the importance of contraception for this country was gradually recognized.

William H. Draper, Jr. urged Congress in 1963 to increase its awareness of the population problem. He felt that a major funding effort was necessary to establish coordinated research through the National Institute of Health. (Plotrow, 1973:76) This was accomplished later in the same year.

More activity followed. on July 20, 1963, Senator J. William Fulbright proposed an amendment that would authorize more research into population control. only three weeks later Senators Joseph S. Clark (D-Pa) and Ernest S. Gruening (D-Alaska) introduced a resolution (S. Con. Res. 56) that would fund increased research in the National Institute of Health. (P1otrow, 1973:78) These were significant steps. Attitudes had changed sufficiently to allow their introduction and ultimate passage. Additionally, an amendment to the foreign aid bill was adopted that allocated funds for research of the population problem in nations receiving ald.

The Department of Health, Education, and Welfare issued a report in 1963 that listed a total of 758 different research projects dealing with human reproduction and contra- 
ception. The projects were costing an estimated 䛍8.2 milition, 4 milition of which were federal funds. (Westoff, 1968:310) This cooperation between federal and private agencies was in all probability a direct outgrowth of Secretary of State Dean Rusk's earlier efforts.

other significant events also occurred in 1963. The Social Security Amendment was passed and authorized the Maternal and Infant Care Projects to incorporate birth control services into their definition of comprehensive maternity care. (Rosoff, 1973:9) In April, the National Academy of Sciences issued its first population report; it stated that government involvement was needed to curb population growth on an international level and that. domestically, birth control services were an essential part of U.S. health care programs. (Jaffe, 1966:3) This report combined the themes of the two parallel movements, voluntary utilization of birth control and population stabilization. Also in that year, Governor Nelson Rockefeller urged the creation of a presidential commission to study the population problem. Cabinet members were opposed to this idea because they felt that it would unnecessarily precipItate a confrontation between President Kennedy and the Catholic Church. Federal funds and support of birth control programs did not come about unt1l the Johnson administration. (Piotrow, 1973:89)

President Johnson, as mentioned earlier, was the 
first Chief Executive to give positive support to birth control. In his State of the Union Message on January 4. 1965, he noted:

I will seek new ways to use our knowledge to help deal with the explosion in world population and the growing scarcity in world resources. (P1otrow, 1973:89)

This statement sanctioned and encouraged federal agencies to move forward and examine the questions of birth control services and population growth.

The first federal agency to respond to President Johnson's authorization was the office of Economic Opportunity. As part of 1ts ant1poverty program, grants were made to community-action agencies for family planning projects. By the end of 1965 twelve projects were operating through grants from OEO. (P1otrow, 1973:91)

Senator Ernest S. Gruening conducted hearings on U.S. population in 1965. Public attention was focused on these hearings and awareness sharpened; the need for federally subsidized family planning and population research programs became obvious. (Commission on Population Growth. 1972:254) Prior to the Gruening hearings most rhetoric dealing with birth control was attached to foreign ald; increasingly, the relevance to domest1c issues was apparent. Another development in 1965 followed the Gruening hearings; recognition of the need for service programs 1ncreased. Unt1l this time emphasis had been on research and the need for allocating funds for this purpose. Service 
delivery now became an equally important issue. The technical development of the birth control pill and the intrauterine device (IUD) made such programs feasible, if funding could be arranged.

The Gruening hearings changed the tone of the discussion regarding birth control in this country. Prior to the hearings the most frequent question was: "How can you justify using taxpayers' money for a cause that many taxpayers consider immoral?" Following the hearings the dominant theme was, "How can you justify withholding such important and useful information as birth control from the poor and disadvantaged who want to have it?" (P1otrow, 1973:107) The issues which concerned government policy planners during the hearings, as reflected in these questions, were freedom of information, civil liberties, and the right to personal freedom of choice. (Plotrow, 1973:107) Denying access to birth control information simply did not withstand close scrutiny when considering these issues. This nation's traditional interest in freedom of cholce has been a major factor in determining the emphasis of birth control.

With the Johnson administration's emphasis on poverty and social issues and the impact of the Gruening hearings, 1966 proved to be a formative year in the development of the birth control movement. Perhaps the most definitive pronouncement of federal intentions came in President Lyndon 
Johnson's 1966 Health Message to Congress:

We have a growing concern to foster the integrity of the family and the opportunity for each child. It is essential that all families have access to information and services that will allow freedom to choose the number and spacing of their children within the dictates of individual conscience. (Harkavy, 1969:368)

This was followed by a statement from Secretary Gardner of the Department of Health, Education, and Welfare, when he Indicated the federal plan was,

\footnotetext{
to 1mprove the health of the people, to strengthen the integrity of the family and to provide families the freedom of cholce to determine the spacing of their children and the size of their families. (Shlakman, $1968: 77$ )
}

Considering the prolonged period of governmental silence, these two pronouncements indicated a turning point in governmental attitude and position.

Congress responded to the aforementioned messages by earmarking funds for two domestic birth control efforts in 1966. These included service projects within the antipoverty program and HEW's Maternal and Child Health programs. (P1otrow, 1973:141) Funds continued to be appropriated at a slow pace, but considering the vold of previous decades 1t was considered by most supporters as progress. However, the slowness with which Congress responded and with which birth control programs were implemented was a source of concern to many. This was a reflection of governmental priorities; birth control simply was not high on the list. 
Frederick Jaffe hypothesized that the slow response was related to general health-care priorities in this country; the 1ssue was quality care for a few or "basic core services" for the masses. (Jaffe, 1973b:23) Increasingly, the focus was put on basic services for the bulk of the population; this included provision of birth control services. As the nation progresses through the 1970 s this has become more pertinent in terms of health care priorities, with the issue of National Health Insurance moving to the forefront.

The government was rumbling slowly toward developing a clear policy, and programs to implement that policy, by 1967. The delays in the formation and implementation process were found largely within government itself. The bureaucracy got in 1 ts own way. As Plotrow noted,

By $196 ?$ the greatest enemy of federal birth control programs appeared to be not the Catholic Church nor the black militants but rather the ponderous workings of the federal agencies themselves. The older, the bigger, the more complex, the more professional the agency, and the more insulated from substantive committees in Congress, the longer it took to institute new programs related to population or family planning. (1973:142)

This is exemplified in a 1967 review of the Department of Health, Education, and Welfare which revealed that none of the department's operating agencies had an understanding of what the expectations were regarding famlly planning; consequently, a high priority had not been assigned. 
(Jaffe, 1973b:20) Perhaps in an effort to remedy this situation, the Secretary of Health, Education, and Welfare appointed a Deputy Assistant Secretary for Population and Famlly Planning; this title was subsequently changed to Deputy Assistant Secretary of Population Affairs. (Commission on Population Growth, 1972:248) This change of title, that 1s, dropping "family planning," may be indicative of a gradual shift of governmental emphasis from birth control to population control. A new focus on the problem may be developing.

Congress and other agencles also increased their level of activity regarding birth control in 1967. An office of Economic Opportunity amendment was passed which elevated birth control to a significant role in the anti-poverty program. Amendments were also passed to Title $\mathrm{V}$ of the Social Security Act which allotted a minimum of 6 percent of Maternal and Child Health funds to be used for birth control services. Congress also amended Title IV-A of the Social Security Act to require provision of birth control services in all states on a voluntary basis to all persons receiving public assistance who were deemed "appropriate." The amendment also urged the programs to prevent 1llegltimate pregnancies. (Goldman, 1971:19) In part, the Title IV-A amendment reads:

Acceptance of any services must be voluntary on the part of the individual and may not be a prerequisite or impediment to eligibility for the recelpt of any other service or ald under the plan. (Goldman, 1971:27) 
- The Office of Economic Opportunity was also expanding its activities in the area of birth control. OEO's budget for birth control services had reached $\$ 4.1$ million by 1967. (Rosoff, 1973:9) Regulations and guidelines for the implementation of birth control programs were appearing, as in Title IV-A. The Department of Health, Education, and Welfare established its first guidelines in 1968. They stated in part:

Family planning services must be of fered and provided to those individuals wishing such services; specifically including medical contraceptive services (diagnosis, treatment, supplies, and follow-up). social services and educational services. Such services must be avallable without regard to marital status, age or parenthood. Individuals must be assured choice of method and there must be arrangements with varied medical resources so that individuals can be assured choice of source of service. Acceptance of any services must be voluntary on the part of the individual and may not be a prerequisite or impediment of eligibility for the receipt of any other service or aid under the plan. Medical services must be provided in accordance with the standards of other state programs providing medical services for family planning (e.g.. maternal and child health services). (Federal Register, 1969:1356)

Other activities in Washington were evident in 1968. The Center for Population Research was created; it operated within the National Institute of Child Health and Human Development. This group carried on considerable research regarding methods of contraception and other factors in population stabilization. In 1972 it was recommended by the Commission on Population Growth and the American Future that a National Institute of Population Sciences be estab- 
Iished within the National Institute of Health to provide a better research framework. (Commission on Population Growth, 1972:149) Indicative of the slowness of the bureaucracy, this has not yet been carried out.

President Johnson also took active steps in 1968 when he established the Committee on Population and Family Planning. The committee recommended rapid expansion of federal birth control programs for the poor, increased research in both biological and social sciences, government subsidizing of population research centers, and increased aid for population control on an international level. (Westoff, 1973:164)

In the midst of this mobilization of government. albeit slow, the population control activists and environmentalists became highly vocal. Paul Ehrlich, a professor of biology at Stanford University, Iinked environmental deterioration with population growth in 1968. This issue became a rallying point for many activists seeking reduction in the population growth rate. Zero Population Growth, Inc. ( $Z P G)$ was created as a vehicle to increase awareness and publicize their convictions. (Westoff, 1973:165)

The population control advocates were alarmed that programs were forming in terms of voluntary utilization, 1.e.. a birth control policy, instead of in the form of a population control policy. Though legislative developments were not occurring as they had hoped, their efforts had 
nonetheless played an important role in the activity of the 1960s. As more of the population recognized the reality of the situation, increasing pressure was put on government to do something about it. The environmentalists also provided a new "enemy" for the movement, thereby strengthening 1t. This new enemy was less tangible than Anthony Comstock had been, but was nevertheless real; 1t was the threat to the quality of ilfe on this earth.

President Richard Nixon was more verbal on the issue of birth control than any government leader before him. This was perhaps a result of the pressure of the times, for Congress was active and the public was aware. It would have been difficult for any president of the late 1960 s to ignore this issue. Nixon addressed himself to national goals regarding family planning:

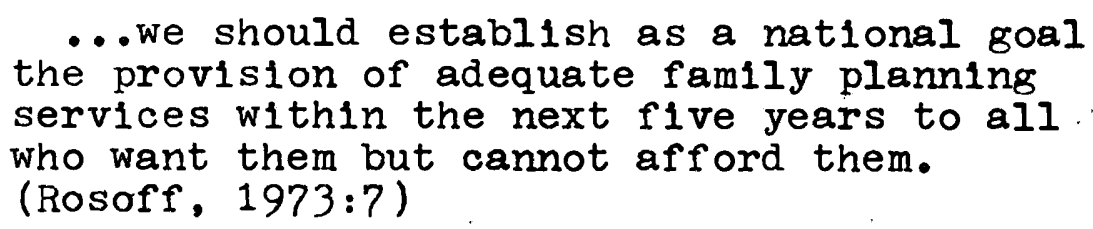

Nixon also addressed the health and poverty issues:

... involuntary childbearing of ten results in poor physical and emotional health for all members of the family. It is one of the factors which contribute to our distressingly high infant mortality, the unacceptable level of malnutrition and the disappointing performance of some children in our schools. (The People Pack, 1972:28)

The increasing emphasis on the population problem, heightened by Ehrlich's publications in 1968, demanded attention from the administration. Nixon responded: 
For some time population growth has been seen as a problem for developing countries. Only recently has it come to be seen that pressing problems are also posed for advanced industrial countries when their populations increase at the rate that the United States, for example, must now anticipate. Food supplies may be ample in such nations, but social supplies - the capacity to educate youth, to provide privacy and living space, to maintain the processes of open democratic government - may be grievously strained.

I belleve that many of our present social. problems may be related to the fact that we have had only fifty years in which to accomodate the second hundred million Americans.... And it now appears that we will have to provide for a third hundred million Americans in a period of just thirty years. (The People Pack, 1972:26-27)

These statements notified birth control advocates, population activists, and environmentalists that Washington was at least interested in what they were saying.

Senator Joseph D. Tydings (D-Md) introduced a bill in Congress in 1969 that would create a new funding source for birth control services. His proposed legislation authorized money for service projects ( 180 million) and for research (\$150 million). (Rosoff, 1973:9) The Ninety-first Congress passed what had become known as the Tydings Bill in December 1970. It was titled the Family Planning Services and Population Research Act of 1970 (Public Law 91-572, S. 2108). (Westoff, 1973:165) Th1s act accomplished several things: it was the first federal authorization of funds specifically for family planning services and it provided a three-year authorization of :225 million. (The People Pack, 1972:119) These funds were 
sanctioned for the following purposes: support of research for new methods of contraception; manpower training and the preparation of educational materials; increasing accessibility of services for an estimated five million low-income women who lacked service; and, creation of the office of Population Affairs within the Department of Health, Education, and Welfare. (The People Pack, 1972:119) The office of Population Affairs, which was established prior to the bill's passage, assumed the responsibility for administering the Title $V$ family planning project grants in october 1969. (Rosoff, 1973:10) The year 1969 was more than the end of a decade, it was a new beginning in the field of birth control services and funding.

Legislation in 1970 maintained the momentum achieved in the previous several years. Iegislative authority for birth control service programs was cemented with the passage of Title $X$ of the Public Health Service Act; Titles IV-A, $V$, and XIX of the Social Security Act; and Title II of the Economic Opportunity Act. (Rosoff, 1973:8) This legisiation conf1rmed the government's stand on the necessity of provision of birth control services. Research was also authorized to a greater extent in 1970 when Title IV-E and $X$ of the Public Health Service Act was passed. (Rosoff, 1973:8) It was in 1970 that both services and research projects were placed under the direction of the newly created Office of Population Affairs, in hopes of maintaining 
continuity of effort. (Rosoff, 1973:16)

The Commission on Population Growth and the American Future (Public Law 91-213) was created by President Richard N1xon on March 16,1970. (Westoff, 1968:356). Th1s was a singularly important event. The Commission's report was issued in 1972, titled population Growth and the American Future, and had numerous recommendations regarding future action of government.

The year 1971 also hosted a landmark event. It is interesting that in spite of all the government activity that was occurring, the Comstock Law was still standing. It was not until January 8, 1971, that Congress repealed the 1873. law. (Commission on Population Growth, 1972:167)

The Commission on Population Growth and the American Future addressed itself to policy considerations and goals, as well as specific recommendations for improvement. They were quick to point out that the United States government did not have an explicit population policy; rather, they indicated that most federal programs operated with little attention to the effects on population growth. (1972:252) However, though no well-defined birth control or population policy existed, the Commission readily agreed with the population control advocates that there seemed little indcation to encourage more growth.

Neither the health of our economy nor the welfare of individual businesses depend on continued population growth... we must conclude that continued population growth 
is definitely not in the interest of promoting the quality of life in the nation. (Commission on Population Growth, 1972:117)

The Commission, while recognizing the problems of too much growth, emphasized freedom of choice of the individual as the birth control movement had been prone to do from its beginning. They stated their policy goals as:

(1) maximize information and knowledge about human reproduction and its implications for the family; (2) improve the quality of the setting in which children are raised; (3) neutralize...those legal, social, and institutional pressures that historically have been mainly pronatalist in character; (4) enable individuals to avoid unwanted childbearing... (Commission on Population Growth, 1972:122)

The Commission's recommendations for implementing these policy goals were voluminous. It is possible, however, to focus on the main themes of their report. The importance of education of the population was recognized and the enactment of a Population Education Act to aid schools in establishing sex education programs was recommended. (Commission on Population Growth, 1972:125) Education of the general community was also emphasized in terms of birth control methods and the population problem; this could be achieved through community organizations, the news media, and the schools. (Commission on Population Growth, 1972:137) The Commission also felt it essential to remove all legal restrictions prohibiting minors from obtaining or using contraceptive information 
and services. It was also recommended that restrictions be removed from obtaining voluntary contraceptive sterilizations. Liberalization of the abortion laws was considered imperative. (Commission on Population Growth, 1972:166) The identification of these factors was an important step in recognizing additional mechanisms for dealing with the population problem.

The Commission also considered matters of funding. They predicted that by 1975 the bulk of birth control funding would have to come from the federal government because of increasing costs and growing utilization. Government investment in research and health services related to fertility was encouraged. (Commission on Population Growth, 1972:166) The Commission urged that funding levels for family planning project grants be increased considerably; they proposed funding levels of \$225 million in 1973. \$275 million in 1974, \$325 million in 1975, and $\$ 400$ million each year thereafter. (Commission on Population Growth. 1972:188) They felt that these funds, coupled with private funds, should help cover financing of all health services related to fertility.

...public and private health financing mechanisms should begin paying the full cost of all health services related to fertility, including contraceptive, prenatal, delivery, and postpartum services; pediatric care for the first year of life; voluntary sterilization; safe termination of unwanted pregnancy; and medical treatment of infertility. (Commission on Population Growth, 1972:185) 
In terms of population growth, the Commission urged the nation to "...welcome and plan for a stabilized population." (Commission on Population Growth, 1972:192)

In encouraging wider support of birth control legislation, the Commission noted that more than half the states in the.country had active statutes which prohibited or restricted the sale, distribution, advertising or display of contraceptives. These states were chastised by the Commission; they felt birth control needed to be avallable to all.

By prohibiting commercial sales, advertising displays, and the use of vending machines for nonprescription contraceptives, they sacrifice accessibility, education, and individual rights in the interest of some undefined purpose. (Commission on Population Growth, 1972:168)

The Commission dominated the year 1972 with its pronouncements and recommendations. However, other organizations were also active. The Executive Board of the American College of Obstetricians and Gynecologists stated in 1972 that they felt attention needed to be given to the young, single female and her need for contraceptives.

The never-married, never-pregnant, sexually involved female has not yet been reached with effective contraception. The laws of some states indirectly prohibit this service to minors and thereby prevent the gynecologists from serving them or place the physician in legal jeopardy if he does so. (Commission on Population Growth, 1972:169-170)

This was considered a reasonable stand and gradually most state laws have liberalized to allow free access to birth 
control services for minors and the unmarried. However, this was not the case in 1972.

Funding increased in 1972 following the Commission's recommendations, though not necessarily a direct result of it. The Committee on Finance proposed full federal funding. of birth control services with no local.matching required. Congress was reluctant, but did pass legislation allowing. for funding of up to 90 percent of expenditures for birth control service projects. (Rosoff, 1973:11)

Medicaid and Title IV-A had somewhat increased the availability of birth control services to many low-income families. In 1972 Congress imposed a ceiling of $\$ 2.5$ billion on expenditures for these programs. (Rosoff, 1973:11) Additionally, states were to receive their allocations on the basis of population rather than demonstrated need; this severely limited many programs. Legislation also redefined those eligible for Title IV-A benefits; single individuals or married persons with no children were to be excluded. This was unfortunate, for this group had been particularly singled out by the Social Security Amendments for services. (Rosoff, 1973:12) Considering the expanding role of services, some felt it was overly pessimistic to receive these restrictions with a sense of foreboding. There was less governmental activity the year after the Commission's report. The major topic of discussion during that period was a debate between the population 
control advocate's societal focus and the birth control movement's emphasis on individual rights. Birth control was still not among the higher priorities of the health care professions. The goals of neither the population control advocates, who maintained a macro or societal perspective, nor the birth control movement, which held to a micro or Individual perspective, were being met. However, some felt that increasing government programs might satisfy both groups in the future. According to Frederick Jaffe,
-..government policies and programs to maximize free choice in reproductive matters will not only help. individuals to achieve their personal goals, but will also go a long way toward achieving the societal goal of slower population growth and, ultimately, stabilization. (1973a:402)

Jaffe has also stated that it is entirely possible that government's emphasis on the individual will ultimately lead to society's benefit, that millions of individual decisions "...may well add up to a national pattern that significantly affects the future growth of the U.S. population." (1972:111) Jaffe went on to say regarding the government policy that had developed:

... a national policy and program to reduce unwanted pregnancy is related to both overall population and social policy. The ability of individual couples to control fertility successfully is, under current circumstances, a necessary condition either for reaching defined demographic objectives or for improving their social functioning and their chances in life. (1972:115) 
SOCIAL ATTITUDES

Wany factors have encouraged the development of a national birth control policy. The foundation for development was established by mid-century, through efforts previously discussed. A simplified view of early efforts toward policy formation indicate a coalition between the birth control activists and professionals. The activists stimulated public attention and awareness while the professionals studied issues, away from the public controversy, in terms of professional values. (Plotrow, 1973:7) "In many ways the story of the development of birth control policy is a story of the professionalization of the activists and the activation of the professionals." (Piotrow, 1973:7) This awareness was not found solely in the public; government was also involved by the late 1950s. Until the beginning of the present era the United States government claimed few social responsibilities; that is, the welfare system was not developed and few government programs existed to help members of the population in economic, physical (medical), or psychological need. This was the case even during the Depression. Because of this, birth control was viewed as an inappropriate concern of government. The early 1960 s saw changes in this attitude. An examination of social factors influencing policy formation during this period would be helpful. 
The birth control activists were concerned with individual rights regarding fertility control and child spacing; it was generally felt that this was a logical first step in the eventual development of a population growth policy, though that was not and is not their goal. The population controller's continued to stress the importance of a societal goal of population stabilization; they wanted to pursue mechanisms beyond contraception, ster111zation and abortion.

Numerous individuals were involved in birth control policy formation during this period. John D. Rockefeller III, Hugh Moore, and William H. Draper, Jr. were among the most active and influential. (Plotrow, 1973:xv) However, the following were also extremely important in bringing government to a new level of awareness and deserve mention: Senators Fulbright, Gruening, Clark, Tydings, Taft, Packwood, and Cranston, and Congressmen Morgan, Hays, Findley, Scheuer, Bush, and DuPont. (Piotrow, 1973:xv) All of these individuals played a vital role in encouraging pol1cy development in the 1960s and 1970s. Early in the birth control movement individual rights were emphasized. The social work profession felt that,

Giving people the access to the means to control the size of their families is an expansion of human options that should rank high among social work's commitments to human rights. (Haselkorn, 1971:7)

Government determined in the 1960 s to implement the birth 
control movement's micro perspective. Emphasis gravitated to the individual. "In the absence of such a national goal for the United States, we are left with the summation of millions of individual family goals: that the rate of unwanted babies be zero." (Corsa, 1966:271)

Because a value was being placed on individual rights, the importance of human dignity also came into the picture. Many people could not afford birth control services as provided through private physicians and agencies; the government's responsibility began to clarify. By 1969 a trend had developed to provide birth control information and services to families receiving their medical care at government supported facilities. (Corsa, 1966:263) 'The importance of maintaining human dignity within the bureaucratic system became clear. Frederick Jaffe stated,

...publicly financed birth control programs are voluntary medical programs which can only succeed if they are offered with compassion and respect for the dignity of patients, and delivered with energy and skill. (1966:8)

The medical aspect of birth control policy is mentioned here and it is singularly important. It was the acceptance of birth control as a medical service that facilitated government support of programs. Vera Shlakman in her article, "Social Policy Issues," stated:

Good policy requires that information and referral be avallable and that they be provided in the same way as for any other medical, educational, or social service. (1968:83) 
In other words, birth control was being included in what was considered comprehensive medical care.

The emphasis on birth control as a health measure continued to gain credibility among the professions. Florence Haselkorn, Adelphi University School of Social Work, said in this regard,

...family planning, seen as a vital need for which services are required, has, within very recent years, achieved wide sanction and legitimacy, through public opinion and legislative and judicial processes which have removed important barriers and moved the field away from the margin of illegality where it was poised for so long. Family planning is now part of national social policy, vigorously affirmed by numerous governmental and voluntary health and welfare agencies and by related organized professional groups. (Shlakman, $1971: \mathrm{xv}$ )

Emphasis on individual rights and consideration of birth control as a medical service had considerable impact on early legislation. Those emphasizing individual rights capitalized on this health care rationale to a great degree. Shlakman also stated regarding this,

The main theme that marks current development of family planning policy at operational levels bases itself on the principle that all families, by free choice, should have the opportunity to space pregnancies and limit family size. (1969:73)

While focusing on individual rights and goals, the government did not lose sight of rapid population growth. President Hichard Nixon created a Commission to study population and related problems in 1970. The President's Commission on Population Growth and the American Future, 
whose report was published in 1972, stressed the importance of population stabilization. They felt this was an achievable goal.

Population stabilization under modern conditions of mortality means that, on the average, each pair of edults will give birth to two children. (Commission on Population Growth, 1972:194)

However, even if this were achieved immediately, population growth would continue for some time because most children who w1ll be parents before the year 2000 have already been born.

The population control advocates have not been entirely happy with the trend of the birth control movement and subsequent governmental activity. The consensus among this group is that individual control over fertility will not control population growth. Kingsley Davis, Director of International Population and Urban Research at University of California in Berkeley, has stated:

The things that make family planning acceptable are the very things that make it ineffective for population control. By stressing the right of parents to have the number of children they want, it evades the basic question of population policy, which is how to give societies the number of children they need. By offering only the means of couples to control fertility, it neglects the means for societies to do so. (1967:738)

Davis goes on to say:

...1t does not make sense to use family planning to provide national population control or planning. The 'planning' in family planning is that 
of each separate couple. The only control they exercise is control over the size of their family. (1967:732)

Other population control advocates seem to support Davis' view. They are in disagreement with the mechanisms the government has chosen and continue to work to expand them. They concur that rights of individuals are important, but not as important as the preservation of the society. Population control advocates want a population policy, not a birth control policy. They emphasize that the societal, or public, good (as well as its preservation) takes priority over the rights of individuals to determine their own fertility rates. Though the population control movement appreciates the efficacy of voluntary utilization of birth control in terms of individual health, they encourage government to expand its means of achieving population stabilization. These were discussed in the section on the population control movement's orientation.

Varying goals also exist among population control advocates; it is felt by some that a population policy should not be limited to growth rate goals. They stress this, while being fully aware that an explicit policy is still nonexistant. Charles Westoff, Associate Director of the Office of Population Research at Princeton University, stated:

...the United States does not yet have an explicit population policy, if that term includes a population growth goal...population policy is and should be a much broader concept 
than a rate of growth and the means to achieve 1t. It should include opportunities for couples to reproduce under optimal circumstances, a notion that includes considerations of the health of the mother and baby and a maximum of freedom of choice for the couple about marriage and the reproductive decision. (1973:175)

The Commission on Population Growth and the American Future agreed with the population control advocates in concern over rapid growth. However, they appeared to feel that there were natural factors in this country favoring stabilization without government intervention. These factors included a trend to smaller family size, declining birth rate over the last decade, increasing employment and expanding roles for women, a general concern over population growth and its effect on the environment, and increasing age at marriage, increasing technical quality of contraceptives, legalization of abortion, and the feasibility of sustained replacement levels of reproduction as shown by other countries. (Commission on Population Growth, 1972:196-197) Though the Commission stressed these naturally favorable factors, they also pointed out that there are unfavorable elements in our society concerning population stabilization; specifically, they referred to our "ideological addiction to growth," the pronatalist stance of many social institutions, and the absence of minorities in the economic mainstream which of ten prevents their achieving small family goals. (Commission on Population Growth, 1972:197-198) 
The importance of human welfare and quality of Iife also gained recognition during the 1960s. Both the health and welfare rationales played strong roles in the birth control movement. (Jaffe, 1973a:403) The needs of children were emphasized. All children need "...some minimum amounts of food, shelter, protection, and education; and the good of society is served by insuring that they receive it." (Commission on Population Growth, 1972:161). It was also recognized that unwanted fertility tends to be highest among those with low levels of income and education. (Commission on Population Growth, 1972:163) An abundance of large families in low income groups led to the generalization that these people liked having large families and were not interested in effective birth control. Considerable evidence to the contrary has been accumulated. The Commission on Population Growth and the American Future stated:

... if blacks could have the number of children they want and no more, their fertility and that of the majority white. population would be very similar. These figures about our black population illustrate the inequality of access of our minority population to the various means of fertility control. (1972:164)

Access to and availability of birth control services for low-income groups will be discussed in greater detall when economic influences on birth control are considered.

Other changes were occurring in the 1960 s that ultimately had considerable impact on the movement. The 
environmental protection issue and women's rights came into

their own during this decade. Public awareness of these

issues increased and their influence grew.

At first these ideologies had little impact on government population programs but gradually they provided strong reinforcement for existing programs and increased urgency for new ones. (Piotrow, 1973:187)

The women's rights movement did much to educate the population regarding alternatives for women.' 'Iraditional roles and attitudes began to change.

Above all it is the feminine view of motherhood which has altered. Fatalism, resignation, passivity or a brave acceptance of fate....this attitude of women who had blindly to submit to fecundity and fulfill the obscure designs of nature had disappeared, or rather is disappearing with the abrupt decline in infant mortality and with its logical corollary, family planning. (Sullerot, 1971:66)

The women's rights movement also emphasized the necessity of educating women regarding methods of birth control if any formulated policy is to succeed.

Today it is recognized that a society which neglects the education of its women does so at its peril. Indeed no policy of birth control can succeed if women remain steeped in ignorance and superstition.... A woman who has no status in her family, among in-laws, in her tribe or in her village unless she has an appreciable number of male offspring (her girl children will be counted as surplus) will not seek to plan her family. (Sullerot, 1971:172)

Other value changes were occurring simultaneously with environmental issues and women's rights. As women move out of the home and into the job market, attitudes 
toward marriage and childbearing are changing. The social pressure for married couples to have children is diminishing; it is generally accepted that the childbearing decision should be individual and free from societal pressures. (Commission on Population Growth, 1972:150) As stated in the Commission's report:

It would be particularly helpful if marriage, childbearing, and childrearing could come to be viewed as more deliberate and serious commitments rather than as traditional, almost compulsory behavior. (Commission on Population Growth, 1972:153)

The acceptance of this philosophy by society is becoming noticeable. The impact of childiess marriages on population growth cannot be determined for some time; however, the removal of societal pressures for parenthood is a notable achievement.

Another value change that has influenced both the development of policy and subsequent service utilization is recognition of teenage sexuality. As teenage pregnancies increased, it became apparent to government and society that teens are sexually active; ignoring this does not make it vanish. This recognition and acceptance has led to contraceptive services for minors. As encouraged by the Commission: "Adequate provision of contraceptive information and services, regardless of age, marital status, or number of children, is likely to reduce rates of out-of-wedlock pregnancy." (Commission on Population Growth, 1972:145)

These issues and changing value orientations have 
been significant parts of the birth control movement.

As these shifts in public values, beliefs, and attitudes occurred and government's awareness and activity increased, the professions also responded. Medicine was particularly important, for the classification of birth control as a health care service inextricably connected the two. A significant example of attitudinal change is reflected in the 1965 American College of Obstetrics and Gynecology's official manual, which suggested,

...that contraceptive sterilization be performed on women under 25 years of age only if they had five living children. Women 30 years old needed four children, and women over 35 needed three living children to qualify. (Westoff, 1973:34)

In 1969 the manual dropped all references to age and number of children for voluntary sterilizations. (Westoff, $1973: 34)$

The medical profession also expressed an interest in the young, single, sexually active woman; the Executive Board of the American College of Obstetrics and Gynecology stated :

The never-married, never-pregnant, sexuallyinvolved female has not yet been reached with effective contraception. The laws of some states indirectly prohibit this service to minors and thereby prevent the gynecologist from serving them or place the physician in legal jeopardy if he does so.... The unmarried female of any age should have access to the most effective methods of contraception, even in the case of the unemancipated minor who refuses to involve her parents. (The People Pack, 1972:7) 
Hecognition by the medical profession of its responsibilities in the area of birth control has facilitated governmental involvement.

Another area of social activity from 1960 to the present has been the creation of service outlets for birth control. According to Frederick Jaffe, more than 3,250 hospitals, health departments, and agencies were providing birth control services to between 3.5 and 4.0 million women in the United States. (1974:166) In commenting on this growth of service avallability, he states:

In less than a decade...U.S. law and policy moved from deterring, or at least making difficult, effective voluntary regulation of fertility, to permitting it and indeed using public resources to facilitate it and to remedy some of the deficits deriving from the inequalities in the distribution of medical care. (Jaffe, 1974:167)

The United States had arrived at a point in time where services were available. The question then arose as to whether, and how much, they would be supported and utilized. To investigate this question a number of attitude and use surveys were done throughout the United States. It was found that from 1961-1965 there was a considerable drop in the rate of unwanted births. A decline of 35 percent for whites and 56 percent for blacks was noted. (Westoff, 1973:19) Another study in the early 1960s indicated changing attitudes. In 1960 it was found that 80 percent of all American women favored birth control in general, while 
13 percent favored only the rhythm method. By 1965 the figures had increased to 85 percent favoring birth control in general with only 10 percent favoring only the rhythm method. (Westoff, 1968:59)

The general use of contraceptives was on the increase; this is indicative of attitudinal change. The National Fertility Study was conducted in 1965 under the sponsorship of the National Institute of Child Health and Human Development; it was carried out by Charles F. Westoff and Norman B. Ryder through the office of Population Research at Princeton University. (Westoff, $1968: x v i 1 i)$ Their findings indicated that 97 percent of American couples who were able to conceive utilized birth control at some time. (Westoff, 1968:10) They also found in 1965 that 84 percent of married white women from 18-39 years of age reported having already used some form of birth control. This figure had increased from 81 percent in 1960 and 70 percent in this age group in 1955. (Westoff, 1968:60) By 1970 it was estimated that over 6 million women (1:5) were using oral contraceptives and 1.25 million women $(1: 20)$ were using the IUD (intrauterine device).

Attitudes regarding contraceptive sterilizations were also changing. From 1965-1970 there was a 38 percent increase in the number of the population having sterilizations. (Westoff, 1973:37) By 1970 one out of ten couples with the wife over 45 years of age and the husband living in 
the home were using sterilization for birth control; this entalled 2.75 million couples, half of them choosing vasectomy. (Westoff, 1973:37) Education seemed to have some influence on utilization of the sterilization option, as it does for use of other forms of contraception. One study found an inverse relationship between education and tubal ligations, i.e.. the higher the level of education the lower the number of tubals. The same study noted a direct relationship between the level of education and vasectomies; the higher the level of education the greater the number of vasectomies. (Westoff, 1973:38)

Education is unquestionably an important factor in contraceptive utilization. It has been found that of college graduates, 94 percent use or expect to use contraception and 88 percent have already used 1t. In those women only completing grade school, 75 percent use or expect to use some form of contraception while 65 percent have already used 1t. (Westoff, 1968:62) Education has also been correlated with the success a woman experiences with a method of birth control, particularly the pill. "Those women who had not completed high school... had twice as high a dropout rate as those who had finlshed high school." (Westoff, 1968:112) These utilization patterns are perhaps related to quality of education as much as to level achieved. In a study of women with high school educations it was found that only 2 percent had not heard of 
"the pill" in 1965, whereas 14 percent of grade school dropouts had not heard of 1t. (Westoff, 1968:104-106) It has also been noted that black women use the birth control p111 less than their white counterparts, regardless of education. (Westoff, 1968:106) One last correlation of contraceptive use with education is the finding that the largest proportion of women using birth control pills had four years of college. (Westoff, 1968:104) Again, perhaps these correlations are related to quality of education and lack of access to information and services as much as to level of education achieved.

Contraceptive use among the poor has also been studied. since education among the poor is generally thought to be of a lower quality than in white middle class areas, it is an accurate assumption that many findings correlate with studies regarding education. "Couples classified as poor or near-poor experienced 2.2 million unwanted births during 1960-1965, or 36 percent of all births to these couples." (Westoff, 1968:301) Contraceptive use among the poor is unquestionably occurring at a lower rate than in white middle and upper class communities.

The period 1960-1975 can be seen as a time of growth for the birth control movement. For the first time in the history of the United States the federal government became actively involved with the subject of birth control. Legislation provided a funding base and service programs were 
instituted across the country. Increasing utilization of birth control also indicated that the movement was achieving one of its goals, a change in attitude regarding the legitimacy and importance of birth control. By 1975 the movement saw birth control accepted into the societal structure and value system.

\section{RELIGIOUS INFLUENCES}

Attitudes toward birth control began to liberalize by the 1930 s in most protestant denominations. However, the Catholic. Church was more stringent in maintaining its conservative doctrine. The only conclliation by the papacy was the acceptance of the rhythm method by Pope Paul XII in 1951. (Westoff, $1968: 174$ )

Clergy within the Roman Catholic Church began to urge tolerance of other methods of birth control by the mid-1960s. Father Janssens of the University of Louvain published an article in 1963 stating that the birth control p1ll was not a true contraceptive and therefore was acceptable for use by Catholics. (st. John-Stevas, 1971:5) This was followed in 1964 -with a statement by Archbishop Roberts that the "law. of nature" rationale of the Church was not persuasive, though he would continue to accept the prohibition of birth control on the authority of the papacy. (St. John-Stevas, 1971:5) These pronouncements were the first indications of discontent within the Catholic clergy on the issue of contraception. 
The Church, however, remained steadfast in its opposition. In March 1964 this opposition was outspoken. The District of Columbia appropriated $\$ 25,000$ to establish birth control services in the area's public clinics. This plan was vigorously opposed by the District's clergy and the Archbishop ultimately opened his own clinic in protest to teach the rhythm method。(St. John-Stevas, 1971:29)

A step forward was taken in 1965 when the Ecumenical Council in Rome recognized the existence of "conjugal love." (westoff, 1968:174) Up until this time the Catholic Church had stated the sole purpose of intercourse was procreation. It was hoped that this initial pronouncement recognizing another legitimate purpose in intercourse would pave the way for a broader acceptance of birth control practices. These hopes did not last long. Pope Paul, in 1964, enlarged the commission to study population and family problems originally created by Pope John XXIII. The commission reported back with the majority favoring acceptance of contraception. (Westoff, 1968:178-181) However, on July 25, 1968, Pope Paul issued his seventh encyclical, "Humanae Vitae," and destroyed any expectation liberal Catholics had regarding a change in doctrine. The Pope stated that any means of preventing. conception, other than the rhythm method, was a sin in the eyes of the church. He included in this category therapeutic abortions, contraceptive sterilizations and all other means of contraception. (Westoff, 1968:178-181) A Gallup Poll 
taken shortly after the issuance of this encyclical indicated that only 28 percent of Catholics favored 1t. 54 percent opposed, and 18 percent had no opinion. (Westoff, 1968:188) Many Catholics had been optimistic that following this pronouncement they would be able to practice birth control within the laws of the church. This hope was gone. As noted by John T. Noonan, a Catholic historian and professor of law, the Church was perpetuating the gap that had always existed between official doctrine and laity practice. (Westoff, 1968:165) A study conducted in 1965 indicated Noonan was probably correct. The study found that 11 percent of married Catholic women under the age of 45 were on birth control pills at the time; 21 percent stated they had used birth control pills at some time in the past. (Westoff, 1968:226) A subsequent study in 1970 1llustrated even more widespread usage of contraception among Catholics: 68 percent of Catholic women between the ages of 18 and 39 indicated they were using some method of birth control other than rhythm. (Westoff, 1973:25) As Charles F. Westoff so succintly stated, "It seems abundantly clear that U.S. Catholics have rejected the 1968 Papal Encyclical..." (1973:30) He also predicted that because of laity pressure, official doctrine would ultimately, change. (Westoff, 1973:30) The Catholic Church not only tried to influence practice within its confines, but also in the secular realm. Its impact on funding practices prior to the 1960 s is a 
notable example. According to Hudson Hoagland, the first director of the Worcester Foundation of Experimental Biology, where the birth control pill was initially developed,

The government would give us nothing for work on anti-fertility compounds nor would philanthropic foundations, both for the same political reason; fear of the Catholics. (Douglad, 1970:255)

The Catholic Church has continued its attempts to influence birth control policy in this country. The impact of these efforts appeared to be diminishing until the 1976 Vatican. encyclical condemning sex for pleasure and emphasizing it as a procreative function only. This encyclical also reiterated the Vatican's disapproval of all forms of birth control other than the rhythm method.

\section{ECONOMIC ISSUES}

The economics of birth control policy are essential to any discussion of policy formation; this includes the legislative base for funding. This section will deal with philosophies underlying this nation's economic legislation reparding birth control services. Factors to be considered include basic assumptions related to birth control, the impact of the poverty issue, and a brief overview of some funding legislation.

Unt1l the late 1960s, it is noted that local and state governments prohibited tax supported birth control services. 
(Corsa, 1966:260) This is reflected in the following statement issued by Planned Parenthood regarding this economic aspect of birth control services:
... women who can afford a private consul- tation with a doctor may obtain contraceptive care, poorer women cannot...the law makes the less efficient types of contraceptive available but outlaws the more effective; the poor who depend on public clinics for medical advice are kept ignorant of the subject, many of them being unaware that contraceptives can be obtained at drugstores, provided they are purchased as prophylactics. (St. John-Stevas, $1960: 26)$

Religious and political controversy were the main factors behind this dictum. The ultimate effect of this lack of support was the denial of birth control knowledge and services to low-income families who depend on public tax supported medical care. These services were avallable to most Americans through private sources. This position changed as public support and government awareness of birth control increased. The number of states with local health departments providing birth control services increased from seven in 1960 to twenty-seven in 1965. (Corsa, 1966:261) Figure 4 further indicates the changes in avallability occurring during this time period.

Government agencies concerned with the economics of birth control policy became involved at different rates. Exemplary of this is the Office of Economic Opportunity which offered a more perceptible commitment to birth control in the mid-1960s than did the Department of Health, Education, 


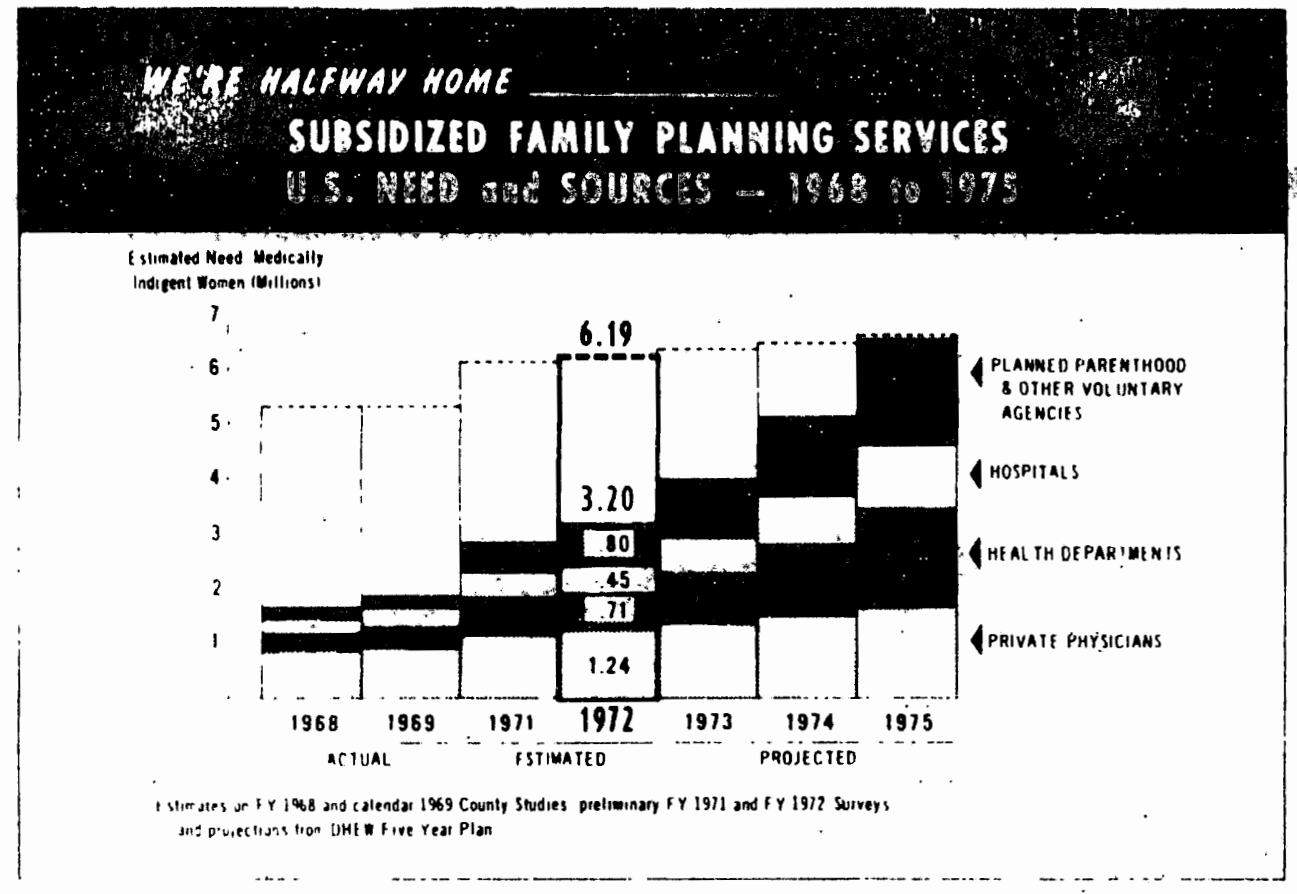

Figure 4. Subsidized family planning services; U.S. need and sources - 1968 to 1975 (The People Pack, 1972:124) 
and Welfare. (Sheppard, 1967:26) Direct delivery of birth control services to the low-income groups at this time was made possible by OEO. Harold L. Sheppard, author of Effects of Family Planning on Poverty in the United States, made the following statement concerning HEW's slowly-developing orientation toward comprehensive health care:

By concentrating on the doctrine of 'comprehensiveness' in its health programs, the department in practice does not mean comprehensive, but rather whatever state and local health departments care to provide. If those departments indicate a preference for family planning services as part of their total offerings, HEW will not object. But apparently HEW will do little to initiate. The desire not to earmark any funds for family planning means in reality that by the time congressional authorizations and appropriations reduce requested funds for all health programs, very little remains for new programs over and above traditional and previous obligations at the local level. (1969:24)

What Sheppard emphasized was that by the mid-1960s no explicit national birth control policy existed. Local and state governments were pursuing or not pursuing birth control at their own discretion; no national directives were available.

Federal agencies continued to emphasize the health and welfare rationale in implementing birth control service projects; others countered that this was not sufficient. The environmentalists and population control advocates were the most vocal in this debate. Suggestions were proffered that would help eliminate the subtle pronatalist policies 
of the nation. Instituting financial rewards to discourage reproduction was in the forefront; it was felt that reversing the present system of tax exemptions would achieve this. (Ehrlich, 1968:136) Other suggestions included placing luxury taxes on many infant 1tems, whlle making sure that essentials would be avallable to the poor. (Ehrlich, 1968:137) It was particularly emphasized that the American public must be awakened to the fact that "...problems associated with population growth will more than cancel the 'advantages' of financial prosperity." (Ehrlich, 1968:151)

The population control movement was not alone in stating the undesirability of continued population growth; the Commission on Population Growth and the American Future was also concerned.

We have looked for, and have not found, any convincing economic argument for continued national population growth. The health of our economy does not depend on 1t. The vitality of business does not depend on 1 . The welfare of the average person certainly does not depend on 1t. (Commission on Population Growth, 1972:53)

It has been pointed out by some authors that population growth has long been associated with economic growth; this causes some to fear that zero population growth would mean zero economic growth. (Westoff, 1973:97) However, population control advocates consider this to be faulty reasoning. They state that the faster the rate of population growth, the less real income there is for each individual; at zero population growth (two children per family) the 
income per person would increase 2.1 times in thirty years and 3.4 times in fifty years。 (Westoff, 1973:99) This is indeed an economically significant reason for curbing population growth.

Another economic factor affecting birth control service projects is related to private industry. Few private insurance companies will finance items such as office visits, drugs, and laboratory tests; these are the essentials of birth control provision, for it is basically an outpatient health service. (Commission on Population Growth, 1972:185)

\section{Poverty Considerations}

A discussion of issues related to poverty is also essential to consideration of economic policy. related to birth control. It is estimated there are twice as many unwanted births in families earning $\$ 4,000$ per year and less, than in families earning $\$ 10,000$ per year and more. (Commission on Population Growth, 1972:165) Perhaps this is indicative of a breakdown in birth control service delivery to low-income groups.

Education, awareness, avallability, and accessibility are factors to consider in low-income utilization of birth control services. Low-income areas are believed to have lower quality educational systems; this contributes to slower academic and social development. Charles Westoff noted : 
According to the 1965 National Fertility Study, among couples under forty-five, only 22 percent of black women were correctly informed about when during their cycles they could become pregnant, while 50 percent of white women were accurately informed. In the South where educational facilities for blacks are most deficient, only 18 percent of black women knew when their fertile period came. And among black women with less than a high school education, only 15 percent had some idea of their fertile period. (1968:259)

This offers some explanation as to why inadequate birth control usage and higher birth rates are evident in most low-income groups.

In considering origins of poverty and its relationship to birth control, emphasis is placed on the premise that birth rates among the poor are not only a result of poverty, they can be a cause of poverty. (Sheppard, 1967:8) B1rth control (1.e., the number, timing, and spacing of births) can lead to conditions that allow for increased income and therefore to a reduction of poverty. (Sheppard, 1967:1) It is known that the proportion of women having more children than they want increases as income level decreases. The question arises as to why low-income groups do not more adequately utilize birth control. Sheppard gives a partial answer in the following statement:

For the poor...the explanation for their high birth rates includes the factor of inadequate funds for birth control devices, but it also includes such factors as unawareness of such devices, unavailability of family planning services, and a host of attitudinal factors (apart from personal religious prohibitions), all of which are subject to change if free 
(or minimal-cost) services are made available and if parents desirous of smaller families are counseled regarding the nonreligious attitudes that may tend to prevent them from actually practicing family planning. (1967;8)

The way in which service is delivered also helps explain why low-income utilization is not what it might be. Long waiting periods, curt staff, demeaning attitudes, and unnecessary questions all inhibit utilization by the poor. According to Vera Shlakman,

...low-income families will use effective
family planning services if they are provided
in an acceptable way, 1.e. with dignity and
respect.. . family planning is a basic health
service that should be avallable through
subsidized public provision like other health
services. (1968:75)

Inadequate utilization of services by the poor has led to some programs directed toward this group. The result of this action has been a charge of genocide by black militants. This charge undoubtedly inhibits some from utilizing services who very much want to, for fear of being considered "traitors" to their race. Broadening the focus of the programs, incorporating minority workers and dealing with infertility problems as well as birth control has helped overcome some anxieties of minority groups. As was aptly put by one writer regarding use of minority personnel, "It is evident that advice to any group on how to limit its numbers comes with best grace from within the membership." (Hardin, 1964:304) This has been implemented by Planned Parenthood with considerable success. According to 
Frederick Jaffe,

There is evidence that when cost and other barriers are removed from access to medical care, and a valuable service is offered, differential utilization of medical services by social class largely disappears. That is the key hypothesis on which planned Parenthood's approach to family planning has been based. Organized famlly planning programs for people of low or marginal income have been growing at an average annual rate of 32 percent a year for five years. (1973b:23)

Before turning to general funding policies, let us consider the cost of birth control programs and their effectiveness. As mentioned earlier, Planned Parenthood has estimated that a 10 million program involving 500,000 women with an annual cost of $\$ 20$ per patient would produce a savings of about $\$ 250$ million. (Sheppard, 1967:19) This savings would be in terms of reduced expenditures on maternal health care, child health care, mental retardation, and welfare costs. (Sheppard, 1967:19) Sheppard considers family planning programs to be the most cost-effective programs avallable in reducing poverty. (1967:22)

The emphasis for remedying the poverty situation in this country is misdirected, according to several authors.

A widely held opinion has been that an increase in family income must precede a reduction in family size, with the policy implication being that emphasis should be placed exclusively on those fiscal, monetary, and structural measures that produce an increase in individual and family incomes. (Sheppard, 1967:1)

The concensus is changing, however, and many now feel that family planning can be utilized as a major instrument in 
reducing and preventing poverty. It is also being recognized that current programs are hardly adequate in terms of the demand in low-income groups.

Dr. Alan Guttmacher, former President of Planned Parenthood-World Population, summed up the needed direction of economic policy during his testimony before the Senate Subcommittee on Employment, Manpower, and Poverty on June 8, 1967:

It is apparent that today in the United States family planning is accepted as an important and necessary component of community health services. The question that faces us today is not whether or not family planning services are needed; it is not a question of beneficial results; it is not even a question of individual or societal acceptance, rather it is a question of the degree of priority we are willing to place on family planning services for the medically impoverished and how far we are willing to go to implement that priority. (Sheppard, 1967:27)

Government is finally turning toward provision of effective mass programs to assist impoverished Americans in controling their family size.

\section{Funding Considerations}

Governmental funding was not an issue in birth control programs until well into the 1930s. At that time private foundations began providing some money for professional and scientific study in the area of population and birth control. (Plotrow, 1973:8) As mentioned earlier, the Scripps Foundation for the Study of Population and the Milbank Memorial Fund were pioneers in this area. These foundations 
ultimately helped bring government funding into the picture. Private foundations "...were an indirect but powerful force impeling the American government toward recognition of the population problem." (Piotrow, 1973:15)

Increasing funds were avallable for birth control programs beginning in 1967; this is indicative of a change in Congressional priorities. (Rosoff, 1973:7)

National Analysts, Inc. conducted a study in 1968 for the Department of Health, Education, and Welfare concerning the cost of birth control projects and the components of the ideal service project. The study revealed that in 1968 the average cost of a project was $\$ 135,000$ a year, though with a sample range of $\$ 27,323$ to $\$ 443,555$. (Okada, 1973:101) The project operating costs were distributed, on the average, as follows:

44 percent: direct medical costs 36 percent: indirect costs (e.g., transportation, child care, follow-up)

20 percent: direct supporting and other costs (Okada, 1973:101)

The cost per patient per year in most of these projects was $\$ 76$. (Okada, 1973:103) The study went on to describe the "ideal" family planning service project: it would have a volume of about 3,000 patients, a budget of $\$ 175,000$, and an institutional base. (Okada, 1973:106) Many projects do not have these ideal operating conditions; most have too many patients, too little money, and inadequate facilities. 
Government funding of birth control projects did increase in the 1960 s, but remained far below what was needed. By 1971, \$27 million was committed directly to research and development of new contraceptive methods. (Westoff, 1973:48) In that year, however, Planned Parenthood received only 42 percent of its operating funds from the federal government, though it remained the core of birth control service delivery in this country. (The People Pack, 1972:115) This lack of federal funds is indicative of the absence of an explicit birth control policy.

The Commission on Population Growth and the American Future recommended increased funding levels for birth control in 1972. They felt that at least 100 million annually was needed for research in reproductive science and $\$ 100$ million annually was also needed for research in contraceptive methods. (Commission on Population Growth, 1972:182) By 1974 federal funding for birth control had reached 150 million, but was still not achieving all the goals whtch had been set. (Jaffe, 1974:166) The year 1975 saw a cutback in funds for birth control services and research. Many feel that this is the beginning of a downturn in funding, in spite of the fact that adequate levels of economic support have never been achieved in this country and an explicit policy has never developed. Where do we go from here? 


\section{CHA PTER VI}

\section{CONCLUSION}

The birth control movement in the United States, beginning in 1873 and extending past the middle of the twentieth century, has been shown to be definable as a social movement. It was initiated by a conflict of value orientations through the passage of the Comstock Law; it was composed of individuals banding together to bring about a change in the social structure; and. it eventually spread to national proportions. The movement persisted over a period of time and remained relatively cohesive in order to achieve its end: the availability of birth control to all who chose voluntarily to use 1 t.

The birth control movement can also be described in terms of those conditions leading to the formation of a social movement:

(1) Men must consciously recognize their dissatisfactions and share these with others. (2) Men must believe in their own ability to reshape the course of their lives. (3) Men must live under conditions in which the banding together to change something is both possible and plausibly effective. (Cameron, 1966:10)

The birth control movement in the United States satisfied all of these conditions.

This dissertation has shown that two parallel movements 
were in existence and were influential regarding this nation's attitude (both public and governmental) toward birth control. First was the birth control movement itself. with its emphasis on voluntary utilization of contraception and an orientation to the individual. The second movement was the population control movement which emphasized the need for a national population growth policy aimed at stabilizing population; their orientation is societal. These movements do have some important similarities, however. First, they both place great emphasis on planning (versus not planning) for the future. They both profess that man's future (individual and societal) is within his control, if only he will exert the effort. Second, both belleve contraception is a legitimate mechanism regarding individual health; disagreement regarding contraception arises in discussing its effectiveness as a means of population stabilization. The population control movement feels contraception alone is not adequate, that broader social policies are needed.

As these two movements passed into the 1960 s there was considerable competition for publicity, public support, and dominance in legislation. This escalation of competition occurred primarily because the public had been awakened to the population control movements perspective: the earth cannot support unlimited growth in a finite sphere. This awakening served the interest of both movements, for 
voluntary utilization of birth control was viewed as one mechanism for achieving population stabilization.

Those advocating voluntary utilization (the birth control movement) dominated government's orientation in the 1960 s and 1970s; legislation reflected the micro perspective. However, the population control movement has persistently worked at increasing awareness of the need for population stabilization both within the government and the public. Social movements are dynamic, changing through time, and it is possible that the population control advocates will eventually gain more influence via legislation.

The dynamic nature of social movements also relates to the conflict theory regarding origins. One might well ask what happens to a social movement when the antagonist is gone, when the battle is won? If a new antagonist cannot be found, a new cause to hold the movement together, it w11l usually disappear or develop into a new social form. (Turner, 1957:480) The birth control movement was instigated by a conflict with the birth control laws of this nation. "Social change which is not accidental comes in response to dissatisfaction." (Cameron, 1966:10) However, the dissatisfaction has not disappeared even though Anthony Comstock and his laws have. The decade of the 1960s saw new emphasis given to an old conflict: the quality of life on earth and continued existence in a finite environment. This "cause" has gained increasing publicity in recent years and 
may well define a new trend in birth control; perhaps the movement will in time shift its emphasis to population control. This has already occurred to some degree, as the birth control movement more and more frequently expresses its interest in population stabilization.

The birth control movement, per se, has diminished In the past few years as a social movement. It has become increasingly incorporated into the structure of society, accepted as a necessary function, and gradually institutionalized. As institutionalization occurs the ramifications of a social movement gradually disappear.

A movement is institutionalized when it has reached a high degree of stability internally and been accorded a recognized position within the larger society. Institutionalization occurs when the movement is viewed as having some continuing function to perform in the larger society, as it is accepted as a desirable or unavoldable ad junct to the existing institutional arrangements. (Turner, 1957:480-481)

This is unquestionably happening to the birth control movement. However, the population control advocates have not yet been incorporated into the societal structure in quite the same way. In speculating on the future of the birth control movement in this country, it is possible to visualize the population control advocates absorbing the birth control movement at the point they are institutionalized. Perhaps in the future decade we will see the birth control movement become one part of a larger population control movement. 
There are certain evidences that a population control movement could emerge. A national leadership has been developing for the past decade, a body of I1terature had become avallable, public awareness has been aroused, and definite social values are seen as requiring change.

This thesis has reviewed the origin of the birth control movement, discussed its growth and development, and traced its institutionalization as a functioning part of society. The development of the population control movement could be the next developmental step. One might then ask, as social theorists tend to do when evaluating movements, "So what?"

The "So what?" of the birth control movement is difficult to answer. It.relies a great deal on future projection and speculation. It prompts one to ask a great many "What if...?" questions. What if the birth control movement had never developed; what would population figures look Ilke today? What if the movement had not encouraged contraceptive research? What if funds continue to be cut for birth control service projects? What if a population policy is, or is not. formed within the next decade? What if the population of the earth is allowed to double, and double, and double...? What if...?

These questions bring one to two distinct points of view regarding the future on this earth: control of one's destiny vs. no control. Those who maintain man has no 
control over his future generally believe that the future is preordained, that little can be done to control what w1ll happen. If the world is to overpopulate itself, that will happen and nothing can be done to prevent 1t. On the other hand, those professing that man does have some control over his destiny insist that the future can be influenced, if only he will exert the effort. They belleve that the world has the potential of being a place of great happlness, peace, and prosperity. Which is correct? It is doubtful that both will prove accurate.

In reviewing the history of the birth control movement, as well as other soclal movements, this writer belleves that neither are wholely accurate. In speculating about the future, this writer feels very strongly that the future can be influenced; it is possible to create a pêfaceful and prosperous world. However, the more basic question 1s, will the people of this earth exert the necessary effort to achieve 1t?

In sum, this writer belleves that what has been achieved by the birth control movement, and what may yet be achieved by the population control movement, are significant value changes. The quality of the effort exerted and the enthusiasm generated for $1 t$ will have a great deal to do with mankind's future on this earth.

The birth control and population control movement's must have a future. If succeeding years are not planned 
for, then perhaps T.S. Eliot was right after all.

this is the way the world ends

this is the way the world ends

this is the way the world ends

not with a bang

but a whimper

"The Hollow Men" 


\section{REFERENCES}

Berelson, Bernard. "Beyond Family Planning," Science,

163 (7 February 1969), 533-542.

Birch, Herbert G。, MD and Joan Dye Gussow. Disadvantaged Children: Health, Nuitrition and School Failure. New York: Harcourt, Brace and World, 1970.

3ogue, Donald J. Principles of Demography. New York: John wiley and Sons, 1969。

Boulding, Kenneth E. "The Utterly Dismal Theorem," The Image: Knowledge in life and Society. Ann Arbor: University of Michigan Press, 1956.

Brown, Farrison S. The Challenge of Man's Future. New York: Viking Press, 1956.

Callahan, Daniel. "Ethical Issues," Concerned Demography, (March 1971).

Callahan, Daniel, ed. The American Population Debate. Garden City, N.Y.: Doubleday, 1971.

Cameron, William Bruce. Modern Social Movements. Niew York: Rand om House, 1966.

Chasteen, Edgar. The Case for Compulsory Birth Control. Englewood cliffs, N.J.: Prentice-Hall, 1971.

Club of iome. The Limits to Growth. New York: Universe Books, $19 \overline{72}$.

Commission on Population Growth and the American Future. Population and the American Future. Washington, D.C.: Government Printing office, 1972.

"Contraceptives and the Law," University of Chicago Law Heview, VI (February 1939), 260-269.

Corsa, Leslie Jr., MD. "The United States," Family Planning and Population Programs. Chicago: University of Chicago Press, 1966. 
Davis, Kingsley. "Population Policy: W1ll Current Programs Succeed?" Science. (November 10, 1967), 730-739.

Douglas, Emily Taft. Pioneer of the Future: Margaret Sanger. New York: Holt, Rinehart and Winston, 1970.

Ehrlich, A.H. and Paul R. Ehrlich, Population, Resources, and Environment. San Francisco: W.H. Freemand and Company, 1972.

Ehrlich, Paul R. The Population Bomb. New York: Ballantine Books, 1968.

Federal Register. Vol. 34. No. 18. January 28, 1969. Section 220.21. 1356.

Fletcher, Joseph. Morals and Medicine. Princeton: Princeton University Press, 1954.

Fryer, Peter. The Birth Controllers. New York: Stein and Day, 1966.

Gil, David A. "A Systematic Approach to Social Policy Analysis," Social Service Review, XIIV, No. 4 (December 1970), 411-426.

Gilbert, Neil and Harry Specht. Dimensions of Soclal Welfare Policy. Englewood Cliffs, N.J.: PrenticeHall, 1974.

Goldman, Joseph and Leonard S. Kogan, PhD. "Public Welfare and Family Planning." Family Planning Perspectives, (October 1971), 19-31.

Gray, Naomi Thomas. "Family Planning and Social Welfare's Responsibility," Soclal Casework, (October 1966).

Guttmacher, Alan F. MD. Pregnancy, Birth, and Family Planning. New York: The Viking Press, 1973.

Hardin, Garrett, ed, Population, Evolution, and Birth Control. San Francisco: W.H. Freeman and Company, 1964.

Harkavy, Oscar, Frederick S. Jaffe, and Samuel M. Wishik. "Family Planning and Public Policy: Who is Misleading Whom?" Sclence, 165 (25 July 1969). $367-373$.

Haselkorn, Florence, ed. Famlly Planning Readings and Case Materials. New York: Counc1l on Social Work Education, 1971. 
Himes, Norman E. Medical History of Contraception. Baltimore: Williams and Wilkins, 1936.

Hoogenboom, Hugo. "Population Policy and Law," Concerned Demography, (March 1971).

Jaffe, Frederick S. Family Planning, Public Policy and Intervention Strategy. New York: Planned ParenthoodWorld Population, 1966.

- "Family Planning Services in the United States," Report of the Commission on Population. Growth and the American Future. Washington, D.C.: Government Printing office, 1972.

"Health Policy and Population Policy: A Relationship Redefined." American Journal of Public Health. (May 1973), 401-404.

- "Public Policy on Fertility Control," Scientific American, (July 1973), 17-23.

"Fertility Control Policy, Social Policy and Population Policy in an Industrialized Country," Family Planning Perspectives, (Summer 1974), 164-169.

King, Wendell c. Soclal Movements in the United States. New York: Random House, 1956.

Lader, Lawrence. Breeding Ourselves to Death. New York: Ballantine Books, 1971.

Lelyveld, Joseph. 'Will we say, 'It just happened,' when the world overpopulates itself to extinction?" The New York Times Magazine, July 19, 1970.

L.F., Jr. "Constitutional Law, Police Power, Birth Control, and Contraceptives," George Washington Law Review, VII (December 1938), 255-257.

Lilienthal, David E. "300,000,000 Amerlcans Would Be wrong," The New York Times Magazine, January 9, 1966.

Malthus, Thomas, An Essay on the Principle of Population. London. 1798 .

McIaughlin, Barry, ed. Studies in Social Movements. New York: The Free Press, 1969.

Merrill, Malcolm H. "The United States Government: A New and Important Factor," Family Planning Programs: an International Survey. ed. Bernard Berelson. New York: Bas1c Books, Inc. 1969. 
Miles, Dudley $\dot{D}$. "The Constitutionality of Anti-Birth Control Legislation," Wyoming Law Journal, VII $(1952), 138-142$.

Notestein, Frank Wo "Zero Population Growth: What Is It?" Family Planning Perspectives, (June 1970).

Okada, Louise M., Gerald Sparer, and Stanley Tillinghast. "How Much Do Family Planning Programs Cost?" Family Planning Perspectives, (Spring 1973), 100-105.

Plotrow, Phyllis Tilson. World Population Crisis: The United States Response. New York: Praeger Pub11shers, 1973.

Pius XII. "Address to Catholic Delegates World Population Congress," The Catholic Mind III, (9 september 1954), 256.

Population and Family Planning. Report of the President's Committee on Population and Family planning. Washington, D.C.: U.S. Department of Health, Education, and Welfare, November 1968.

Place, Francis. Illustrations and Proofs of the principle of Population. (reproduction). New York: A.M. Kelly, 1967.

Bosoff, Jeannie I. "The Future of Federal Support for Family Planning Services and Population Research." Family Planning Perspectives, (Winter 1973).

Sanger, Margaret $\mathrm{H}$. Motherhood in Bondage. New York: Brentanos, 1928.

Sanger, Margaret H. My Fight for Birth Control. New York: Farrar and Rinehart, 1931.

Sheppard, Harold L. Effects of Family Planning on Poverty in the United states. Kalamazoo: The W.E. Upjohn Institute for Employment Research, 1967.

Shlakman, Vera. "Social Policy Issues." Family Planning: The Role of Soclal Work, ed. Florence Haselkorn. New York: Adelphi University School of Soclal Work, 1968.

Sills, David L., ed. International Encyclopedia of the Soclal Sciences. New York: The Macmillan Company and The Free Press, 1968. 
St. John-Stevas, Norman. Birth Control and Public Pol1cy. Santa Barbara: Center for the Study of Democratic Institutions, 1960.

St. John-Stevas, Norman. The Agonising Cholce: Birth Control, Religion, and the Law. Iondon: Eyre and Spottiswoode, 1971.

Stone, A. and H.F. PIIpel. "The Soclal and Legal Status of Contraception," North Carolina Law Review, XXII (Apri1 1944), 212-225.

Sullerot, Evelyne. Woman, Soclety and Change. New. York: McGraw-H1II, 1971.

Sulloway, Alvah W. Birth Control and Catholic Doctrine. Boston: Beacon Press, 1959.

The People Pack. New York: Planned Parenthood Federation of Amer1ca, 1972.

Toffler, Alvin. Future Shock. New York: Bantam Books, 1970.

Turner, Ralph Ho and Lewis M. Killian. Collective Behavior. Englewood Cliffs, N.J.: Prentice-Hall, Inc., 1957.

U.S. Bureau of Census. "Estimates of the Population of the U.S. and Components of Change: 1940 to 1972." Current Population Reports. Series P-25, No. 481 , Washington, D.C.: U.S. Government Printing office, 1972 .

U.S. Congress, Senate. Committee on Government Operations. Subcommittee on Foreign Aid Expenditures. Population Crisis Hearings 1965-1968. Washington, D.C.: Soc1o-Dynamics Publications, 1970.

Westoff, Leslie A. and Charles Westoff. From Now to Zero. Boston: Little, Brown and Company, 1968.

Westoff, Charles F. and others. Toward the End of Growth. Englewood Cliffs, N.J.: Prentice-Hal1, 1973.

Whelpton, Pascal K., Arthur A. Campbell, and John E.

Patterson. Fertility and Family Planning in the United States. Princeton: Princeton University Press, 1966. 


\section{APPENDIX}

IMPORTANT DATES IN THE BIRTH CONTROL MOVEMENT

1873 Comstock Law passed; forbade distribution of contraceptive information by mail

1879 Margaret Sanger born in Corning, New York

1890 Tarriff Law: barred importation of contraceptive literature and supplies

1912 Margaret Sanger initiated birth control movement through her lectures

1914 The Woman Rebel published by Sanger

Family Iimitation published by Sanger

1915 National Birth Control League founded by Margaret Sanger

1916 Margaret Sanger opened f1rst U.S. birth control clinic in Brooklyn; clinic ralded and closed by police; Sanger jailed for thirty days

1917 Committee of One Hundred formed; group of upper class women working within the birth control movement

Birth Control Review published; first national system for communication within movement

1918 New York State Supreme Court (Judge Crane) held that physiclans could prescribe contraceptives for the cure and prevention of disease

1921 Catholics blocked rally at First National Birth Control Conference

American Birth Control League founded by Margaret Sanger

1925 -American Medical Association urged revision of statutes to exempt physicians from ban on contraceptive distribution 
1927 -New York League of Women Voters urged repeal of the Comstock Law

First World Population Conference held in Geneva, Switzerland

1929 Clinical Research Bureau opened by Sanger in New York City; raided by pollce and patient records confiscated

1930 National Council of Jewish Women endorsed b1rth control movement

- Unitarians first religious group to support birth control; followed by presbyterlans, Methodists, and Central Conference of American Rabbis

1933 - Davis vS. U.S.: intent to use contraceptives for illegal purposes held necessary for a conviction under the postal transport statutes

1934 - United States vs. One Package: held that postal law was not intended to prohibit physicians from prescribing contraceptives for the well-being of their patients

1935 NBC ended radio ban on subject of birth control

1937 - American Medical Association accepted birth control as a requisite in medical education and practice

1938 - President Franklin D. Roosevelt appointed committee to study population problems through the National Resources Committee

1942 - Planned Parenthood Federation of America formed through merger of the American Birth Control League and the Clinical Research Bureau

Surgeon General of the United States made first official statement re birth control; allowed states to pay for birth control services through their Maternal and Child Health allottments

1952 International Planned Parenthood formed

Population Counc1l formed by the National Academy of Sclences

1955 National magazine first published article naming methods of contraception 
1959 Birth control first mentioned on television broadcast

- President Dwight D. Eisenhower stated birth control was not the business of the federal government

Draper Committee report issued; stated population problem directly related to U.S. economic ald policy

-New. Jersey law banning sale and distribution of contraceptives found unconstitutional

1960 - The birth control pill was placed on the market

- American Medical Association recommended ali medical students receive instruction in contraceptive methods

1962 Planned Parenthood-World Population created through merger of Planned Parenthood Federation of America and World Population Emergency Campaign

First family planning grant authorized by Congress; $\$ 25,000$ for Washington, D.C. public clinics

Gardner gave United Nation's speech proclaiming U.S. support for international birth control efforts

1963 - Dwight D. Elsenhower retracted h1s earlier statement regarding federal concern with birth control and joined the Sponsors Council of Planned ParenthoodWorld Population

Maternal and Child Health projects authorized to incorporate birth control into their comprehensive services through the Social Security Amendments

National Academy of Sciences issued its first population report

Some discontent within Catholic clergy regarding birth control policy

1965 - President Lyndon Johnson in his State of the Union message gave positive support to birth control efforts

Office of Economic Opportunity issued grants to community-action agencies for family planning projects

Gruening Hearings on population

- Griswold and Buxton vs. Connecticut: held Connecticut law prohibiting use of contraceptives unconstitutional 
1965 - Birth control services beginning to appear in public supported facilities

National Fertility study indicated 97 percent of fertile American couples utilized birth control at some time

1966 - President Lyndon Johnson urged access to birth control services for each family that wanted them

Funds allocated for blrth control service projects through the antipoverty program and HEW's Maternal and Child Health programs

Margaret Sanger died at the age of 87

1967 State VS. Baird: held New Jersey law banning explanation and display of contraceptives unconstitutional

Population control advocates expressed dissatisfaction with trends of policy development

Funds made available for birth control services through Title V and Title IV-A of Social Security Act

Office of Economic Opportunity's budget for birth control services reached $\$ 4.1$ million

1968. Paul Ehrlich published The Population Bomb

Zero Population Growth. Inc. created

Pope Paul issued his encyclical "Humanae Vitae," condemning any form of contraception other than the rhythm method

Center for Population Research created within the National Institute of Child Health and Human Development

President Lyndon Johnson established the Committee on Population and Family Planning

1969 - President Richard Nixon urged that family planning services be made avallable to all who wanted them

1970 - Tydings Bill signed into law; known as the Family Planning Services and Population Research Act of 1970 
1970 Legislative authority for birth control services increased (Title $X$ of Public Health Service Act; Tities IV-A, V, and XIX of Social security Act; Title II of Economic Opportunity Act)

- President Richard Nixon created Commission on Population Growth and the American Future

-..-Supreme Court found Massachusett's law banning sale of contraceptives to unmarried persons unconstitutional

1971 - Congress repealed the Comstock Law

1972 Commission on Population Growth and the American Future published their report

-Congress imposed $\$ 2.5$ billion celling on birth control spending in Medicald and Title IV-A programs; also restricted eligibility for these programs

Relationship of poverty and large families substantiated through research

1975 - Congress cut back funds for birth control services and research; more cutbacks predicted for the future

1976 Vatican issued encyclical condemning sex for pleasure, maintaining its sole purpose is procreation; also continued ban on all forms of contraception other than rhythm 